\title{
Deconstrucción de los relatos evangélicos de la pasión. Sobre el arraigo de la ficción en la Historia de las religiones
}

\author{
Fernando BERMEJO \\ UNED \\ fjlmbr@yahoo.es
}

\begin{abstract}
«New Testament scholars all tell themselves, one another and their students that the Gospel writers were not historians in the modern sense, but we do not apply this fact rigorously enough» (E. P. Sanders, Jesus and Judaism)

«Though this be madness, yet there is method in 't» (W. Shakespeare, Hamlet, acto $2^{\circ}$, escena $2^{\mathrm{a}}$ )

Para Melissa Vallmitjana y Walter Meyerstein
\end{abstract}

\section{RESUMEN}

Las más elementales exigencias de rigor crítico e independencia siguen a menudo sin cumplirse hoy en día en la reconstrucción histórica de la figura del judío Yeshua ben Yosef (Jesús el galileo), en parte porque el carácter inconsistente de las fuentes evangélicas no es tomado en serio. El presente artículo analiza las incongruencias de los relatos de la pasión, muestra en ellos los indicios de un proceso de despolitización, y señala el carácter insostenible de varias afirmaciones clave de muchos historiadores contemporáneos sobre el predicador galileo.

Palabras clave: Evangelios, relatos de la Pasión, inconsistencias, ficción, historia de las religiones.

Deconstructing the Gospel Passion Narratives. On the Fiction Embedded in the History of Religions

\begin{abstract}
Very often the fundamental requirements of critical rigour and independence are still lacking in the historical reconstruction of the Jew Yeshua ben Yosef, which is in part due to the fact that the inconsistent nature of the Gospels is not seriously taken into account. The present article analyses the inconsistencies of the Passion accounts, unveils the presence of an underlying process of de-politicization, and accordingly points to the untenable character of several key statements on the Galilean preacher made by many contemporary historians.
\end{abstract}

Keywords: Gospels, Passion Accounts, Inconsistencies, Fiction, History of Religions. 
SUMARIO: 1. Planteamiento y relevancia de la cuestión. 2. Incongruencias en los relatos de la pasión. 3. Un proceso de despolitización. 3.1. Episodios que implican el uso de violencia 3.2. Ecce homines: Jesús entre los insurgentes 3.3. La pretensión regia de Jesús, o la voluntad de usurpación 3.4. La lógica subyacente y las hipótesis alternativas 4. La persistencia de la ficción en la academia. 4.1. ¿Fue Jesús crucificado entre dos «ladrones»/«delincuentes comunes»? 4.2. ¿Fue Jesús arrestado por iniciativa de las autoridades judías? 4.3. ¿Fue Jesús condenado por «blasfemia»? 5. Conclusiones. 6. Bibliografía.

FECHA DE RECEPCIÓN: 10 DE 12 DE 2014 FECHA DE ACEPTACIÓN: 17 DE 01 DE 2015

\section{PLANTEAMIENTO Y RELEVANCIA DE LA CUESTIÓN}

Si bien el estudio de la religión como un saber genuinamente autónomo, emancipado de resabios teológicos - o antiteológicos-, es sin duda uno de los triunfos del espíritu crítico, la constitución de tal disciplina neutral no ha dejado de encontrar resistencias de distinto signo. Entre ellas, quizás la principal ha tenido lugar en los ámbitos confesionales, en los que una historia libre de constricciones es percibida como una deslegitimación de la tradición y el dogma. No obstante, la respetabilidad de una aproximación científica -nítidamente reflejada en la denominación alemana Religionswissenschaft- ha producido asimismo una serie de metamorfosis adaptativas, mediante las cuales las aproximaciones religiocéntricas siguen efectuando sus reivindicaciones (por ejemplo, denominando «ciencias religiosas» a lo que no son sino doctrinas teológicas o parateológicas) ${ }^{1}$. La «fenomenología de la religión» sirve a menudo igualmente a la estrategia de hacer pasar por estudio riguroso una ideología más o menos crasamente confesional ${ }^{2}$.

La situación es en realidad aún más grave, pues la transmisión de contenidos religiosos en calidad de conocimiento histórico fiable no se confina únicamente a medios eclesiásticos, sino que se da también en ámbitos universitarios públicos, en los que cabría esperar mayor independencia de juicio y acumen crítico. Esto ocurre a menudo en el caso de los orígenes del cristianismo ${ }^{3}$, y en particular en el del estudio de su referente,

${ }^{1}$ Cfr. Díez de Velasco 2002, 365 y 373-4.

${ }^{2}$ Un ejemplo conspicuo en nuestro país es Martín Velasco $1996^{6}$, en cuyas sucesivas reediciones a lo largo de varias décadas diversas formas religiosas son calificadas de «fallidas» y «deficientes» (cfr. ibid., 116, 215, 224, 250); frente a ellas se levanta la religión del autor: «Entre las diferentes manifestaciones históricas del hecho religioso, como una forma especialmente elevada del mismo, se encuentra el cristianismo» (ibid., 301). Sobre el carácter teológico de esta obra, cfr. Bermejo 2002. Finalmente, Martín Velasco eliminó los pasajes más burdamente confesionales en una edición revisada y aumentada (publicada en 2006), aunque las numerosas falacias y deficiencias estructurales de su obra -muy usada hasta hoy tanto en instituciones eclesiásticas como en universidades públicas- persisten.

${ }^{3}$ Basten un par de ejemplos. La distorsión del judaísmo en los estudios sobre la figura de Jesús y los orígenes del cristianismo se prosigue hasta la actualidad, como lo han mostrado p. ej. Crossley 2008, 173-194; Bermejo 2013c. Sobre las distorsiones imperantes en el tema de la persecución, cfr. González Salinero $2015^{2}$; Moss 2013. 
el predicador judío Yeshua ben Yosef / Jesús el galileo. En efecto, en este ámbito siguen ofreciéndose con el marchamo de respetabilidad académica visiones que se limitan a reflejar los relatos evangélicos o que dependen claramente de ellos, a pesar de que el carácter sesgado de estos textos debería ser ya obvio tras varios siglos de investigación.

Aunque los condicionamientos e intereses en juego en todo lo relativo a la religión predominante actualmente en nuestro mundo son comprensibles, el hecho de que la función crítica consustancial a la génesis y al desarrollo de la historia de las religiones brille aquí a menudo por su ausencia y siga siendo un desiderátum constituye una situación epistemológicamente lamentable. En estas circunstancias, el presente artículo tiene varios objetivos complementarios: reconsiderar los graves problemas de verosimilitud histórica que presentan los relatos de la pasión, rastrear en ellos un proceso subyacente de despolitización, y poner de manifiesto a esta luz el alcance de la distorsión de la figura de Jesús en obras contemporáneas que se presentan como historia rigurosa.

\section{INCONGRUENCIAS EN LOS RELATOS DE LA PASIÓN}

El punto de partida de cualquier hipótesis sobre la figura del predicador galileo se halla en un hecho textual incontrovertible: los relatos de la pasión, núcleo de los evangelios, abundan en incongruencias de todo tipo. Señalar los límites de la fiabilidad de tales relatos parecería resultar superfluo, una vez se presupone su carácter de obras sesgadas por necesidades apologéticas y hagiográficas. Sin embargo, conviene explicitar tales problemas con el objeto de ponderar la medida en que afectan a la fiabilidad de lo narrado, pues demasiado a menudo los estudiosos o bien se limitan a presuponerlos, o bien, tras un mero reconocimiento genérico pro forma, minimizan su alcance y en la práctica los olvidan. Ambos procedimientos, aunque contrarios, tienen el mismo funesto resultado: impedir la percepción lúcida del verdadero alcance del problema. El tratamiento efectuado en esta sección, por breve que sea, intenta hurtarse a esta deficiencia discursiva ${ }^{4}$.

Un primer ejemplo lo constituye el décalage perceptible en los relatos evangélicos entre el supuesto carácter de Jesús y de su mensaje social y la reacción que genera en sus propios correligionarios. El predicador es presentado como la quintaesencia de la compasión y la bondad, y como un sujeto que enarbola, entre otros, el ideal del amor al prójimo. Sin embargo, al mismo tiempo es descrito como el blanco de una inusitada malevolencia no solo de parte del pueblo -que llega a impetrar para él la muerte más cruel ${ }^{5}$-, sino también como la víctima de la hostilidad acérrima de sujetos piadosos, que reaccionan con envidia y odio desde el principio: según Mc 3, 6 los fariseos buscan su perdición. Tales reacciones infundadas resultan, en rigor, ininteligibles.

\footnotetext{
${ }^{4}$ No solo el material legendario y milagroso, sino también otros aspectos incoherentes de los evangelios (entre sí y en el seno de cada relato) no relacionados directamente con la pasión son omitidos aquí.

5 Sobre la petición de crucifixión, cfr. Mc 15, 13-14; Mt 27, 22-23.25; Lc 23, 23.
} 
Otra incongruencia, conectada con la anterior, es que, aunque los fariseos son genéricamente retratados como los adversarios par excellence de Jesús ya desde Mc 3, en la tradición que subyace a Mc 14-15 tal enemistad brilla por su ausencia: los fariseos no son mencionados nunca, y como adversarios figuran sacerdotes, ancianos y escribas. Más aún, en los relatos evangélicos se conservan tradiciones que presentan a fariseos respetuosos y aun favorables hacia Jesús -hasta el punto de que algunos le advierten de los planes del tetrarca Herodes Antipas para acabar con él-6.

Una incoherencia análoga se refiere al retrato de los «sumos sacerdotes y jefes del pueblo». En los relatos de la pasión, los evangelistas insisten por doquier en postular la unanimidad de las autoridades judías a la hora de oponerse a Jesús. Sin embargo, varios pasajes ponen en entredicho - hasta el punto de contradecir- la existencia de tal unanimidad, así como la imagen de las autoridades judías como seres moral y espiritualmente mezquinos ${ }^{7}$.

Según todos los relatos, hubo resistencia armada en Getsemaní por parte de alguno de los seguidores de Jesús, y según todos excepto Marcos, Jesús se opone al uso de violencia ${ }^{8}$. Sin embargo, los relatos coinciden en que la persona que supuestamente apela a la renuncia a las armas es la única arrestada y posteriormente crucificada, mientras que la responsable del derramamiento de sangre no sufre perjuicio alguno. Lucas presupone que el resto de discípulos están armados ${ }^{9}$, pero tampoco ellos son, supuestamente, objeto de persecución ${ }^{10}$.

Las autoridades judías son dibujadas como las que toman la iniciativa del arresto de Jesús y de su condena, y ello en virtud de razones eminentemente religiosas (blasfemia). Sin embargo, a Jesús no se le aplica la forma de ejecución (lapidación: cfr. Lev 24, 14; Hch 7, 57-58) que habría estado permitida en este caso de acuerdo con la Ley mosaica. En lugar de ello, se afirma que es entregado a la autoridad romana, la encargada de llevar a cabo la ejecución con una pena romana.

Un individuo caracterizado como políticamente inofensivo, defensor avant la lettre de la no-violencia y supuestamente declarado inocente por el prefecto romano ${ }^{11}$ es sin embargo ejecutado por orden de este mediante crucifixión, considerada el suplicio más cruel y reservado en la Judea del s. I a los sediciosos y culpables de maiestas imminuta, es decir, de un delito contra la seguridad del Imperio, alegándose la pretensión de usurpación en el titulus crucis («rey de los judíos»).

${ }^{6}$ Cfr. Lc 7, 37-50; 13, 31; Jn 3, 1-2. De hecho, como han puesto de relieve diversos estudiosos, buena parte de la enseñanza de Jesús es comprensible en el marco del fariseísmo.

${ }^{7}$ Cfr. p. ej. Lc 23, 50-51; Jn 11, 47-50; Hch 5, 34-40.

${ }^{8}$ Mt 26, 52-54; Lc 22, 51; Jn 18, 11.

${ }^{9}$ Cfr. infra, sección 3.1 .

${ }^{10}$ «Gerade er wird verhaftet, der den friedlichen Weg predigt, dagegen behelligt man nicht im mindesten die Apostel, die ihre Schwerter zogen und dreinhieben [...] Ein ganz unbegreiflicher und sinnloser Vorgang» (Kautsky 1908, 389).

${ }^{11} \mathrm{Mc}$ 15, 5.10 (la presunta inocencia es también testimoniada por el centurión al cargo de la crucifixión: Mc 15, 39; Lc 23, 47). En el Cuarto Evangelio, Pilato declara la inocencia de Jesús tres veces: Jn 19, 4.6.12-18. 
Los evangelistas presentan a Jesús reconociendo el deber de pagar el tributo al emperador, algo que todo judío nacionalista habría interpretado como una forma de colaboracionismo ${ }^{12}$. Sin embargo, según ellos Jesús es aclamado pocos días antes de su arresto como rey-mesías en un sentido inequívocamente político (cfr. Mc 11, 8-10) y es precisamente en calidad de sedicente «rey de los judíos» como es condenado en la cruz ${ }^{13}$. Jesús es descrito, pues, simultáneamente como prorromano y como antirromano.

De acuerdo con los relatos evangélicos, las autoridades de Jerusalén presentan a Jesús ante Pilato como un sujeto sedicioso -algo que el prefecto no parece $\operatorname{creer}^{14}-\mathrm{e}$ insisten una y otra vez en que precisamente por ello merece ser crucificado. Al mismo tiempo, sin embargo, esas mismas autoridades incitan a la multitud para obtener de Pilato la liberación de un tal Barrabás, quien es sin embargo presentado directa o indirectamente como un individuo convicto de sedición.

En el relato de Lucas, se asevera que Jesús es enviado por Pilato a Herodes Antipas, dada la condición de galileo del predicador. Aunque Antipas se burla de Jesús, no lo condena explícitamente y lo reenvía a Pilato, y más tarde este respalda su inconsistente veredicto de inocencia remitiéndose a Antipas ${ }^{15}$. Ahora bien -y dejando aparte las sospechas que suscita el ir y venir de Jesús entre el prefecto y el tetrarca $-{ }^{16}$, en el resto de la obra lucana, y de hecho en toda la tradición evangélica, se trasluce una honda animadversión mutua entre el predicador y Antipas, que llega al punto de que este parece haber buscado la muerte de aquel ${ }^{17}$.

Los evangelios se refieren a una presunta costumbre del prefecto de liberar a un prisionero durante la Pascua ${ }^{18}$. Ahora bien, además de que -a pesar de los

12 Mc 12, 13-17. Lc 23, 2 recoge el cargo de que Jesús soliviantó al pueblo impidiendo pagar el tributo, aunque supone que los cargos son falsos. Según Josefo, Judas el Galileo se opuso al pago del tributo (cfr. A. J. XVIII 2-4; B. J. II 118).

${ }^{13}$ Cfr. Mc 15, 2; Jn 18, 33; Jn 19, 12.15.

${ }^{14}$ Algunos autores pretenden otorgar credibilidad a la reluctancia de Pilato aduciendo analogías de juicios criminales en época julio-claudia: «The story of the reluctance, or at least the surprise, of Pilate, however much it may have been worked up for the propaganda purposes of the authors, is not without Julio-Claudian analogies [...] Roman judges disliked sentencing an undefended man as much as an inadequately accused man» (Sherwin-White 1963, 25-26). El carácter falaz de este razonamiento radica, por una parte, en que obvia enteramente el abundante material que apunta a la implicación de Jesús en la resistencia antirromana (cfr. infra, sección 3); por otra, en que los intentos de legitimar los implausibles relatos evangélicos a la luz de la historia del derecho adolecen de arbitrariedad metodológica y escaso sentido histórico: «Die Auslegungsgeschichte zeigt zudem, dass Versuche, aus den Evangelien 'rechtsgeschichtliche' und 'sozialgeschichtliche' Deduktionen auf die historischen Umstände der Kreuzigung Jesu abzuleiten, auf gravierende Probleme stoßen [...] Noch weit verwirrender wird die Lage, wenn man aus den Evangelien auf die rechtsgeschichtlichen Hintergründe der Beteiligung jüdischer Instanzen an der Kreuzigung Jesu schließen will» (Stegemann 2010, 375-376).

${ }^{15}$ Lc 23, 14. Cfr. Hoehner 1972, 243-245.

${ }^{16}$ El episodio lucano parece, de hecho, el resultado de una aplicación anacrónica del forum domicilii (el principio según el cual una persona debía ser juzgada por el gobernador de la provincia donde vivía). Como indica Lc 13, 1, lo que parece haber predominado -también por razones prácticas- es el principio del forum delicti.

${ }^{17}$ Mc 8, 15; Lc 13, 31.

${ }^{18} \mathrm{Mc} 15,6-8$ sugiere que es la multitud la que toma la iniciativa de solicitar el cumplimiento de la supuesta costumbre. Mt 27, 17 parece indicar que la iniciativa procede de Pilato. 
denodados esfuerzos hechos para encontrar pruebas de su existencia- no existe el menor testimonio de tal costumbre, lo revelador es la intrínseca improbabilidad de esa pretensión: es apenas creíble que a los habitantes de una provincia conocida por su rebeldía -que pocas décadas antes había exigido la sangrienta intervención de las legiones de Siria- se les hubiera concedido el privilegio de liberar a voluntad a un prisionero, y precisamente en el período emocionalmente cargado de la Pascua, la fiesta en la que Israel conmemoraba su liberación de la opresión de un poder pagano $^{19}$.

Otra incongruencia estriba en el modo de aplicación de la supuesta costumbre. Por un lado, se afirma que Pilato, convencido de la inocencia de Jesús, intenta salvarlo, y para ello recurre a la supuesta medida de gracia. Por otro, sin embargo, en lugar de limitarse a liberarlo en aplicación de la medida de amnistía, en el Evangelio de Mateo permite que sea la multitud la que decida. No solo eso, sino que el prefecto da a elegir a la multitud entre un prisionero presuntamente inocente (Jesús) y uno aparentemente involucrado en un episodio sedicioso (Barrabás) ${ }^{20}$. Pero si se opta por prestar atención a la supuesta capacidad del pueblo para elegir libremente al amnistiado ${ }^{21}$ surge otra incongruencia, a saber, que Pilato limita la elección del pueblo a dos posibilidades, a pesar de que según los evangelios otras personas habían sido arrestadas por la autoridad romana ${ }^{22}$.

Mt 27, 24 narra el célebre lavatorio de las manos, mediante el cual Pilato se declara inocente de la muerte de Jesús. Lo implausible de la escena radica en que un prefecto se declare inocente de la muerte de un sujeto al tiempo que ordena su crucifixión (y su humillación: Mt 27, 27-3023), pero también en que lo haga con una declaración solemne en la que se atiene a un procedimiento judío: la escena corresponde, en efecto, al rito expiatorio bíblico en el que uno se exonera de la culpa de homicidio cuando alguien yace asesinado en el territorio de una ciudad y no se conoce al asesino 24 .

${ }^{19}$ Recientemente se ha conjeturado que las escenas evangélicas concernientes a Barrabás podrían haber sido creadas tomando como modelo la política del gobernador Albino (62-64 e.c.), quien -según cuenta Josefo (A. J. XX 208-210, 215)- al parecer para congraciarse con los habitantes de Jerusalén antes de la llegada de su sucesor Gesio Floro permitió la liberación de algunos prisioneros que no habían cometido delitos graves; cfr. Bourgel 2012, 513-520.

${ }^{20}$ «Mark presents Pilate, a Roman governor, not only as criminally weak in his failure to do justice, but as a fool beyond belief. For, if he had truly sought to save Jesus, he could surely have done nothing worse to defeat his purpose than to offer the Jewish crowd a choice between Jesus and Barabbas. To them Barabbas was a patriot who had risked his life against their hated Roman rulers, whereas Jesus, according to Mark, had advised them to pay tribute to these Romans. To have offered the people such a choice, with the intention of saving Jesus, was the act of an idiot» (Brandon 1967, 4).

21 Cfr. Mc 15, 6; Mt 27, 15; Lc 23, 25; Jn 18, 39.

22 «Whilst the evangelists state explicitly that the crowd was free to demand from Pilate the pardon of any prisoner, yet at the same time they imply that the choice was limited to two individuals, The offer to choose between two persons only in fact denies the free exercise of the prerogative of the people's will. On this point the Gospels are self-contradictory in their reports» (Winter 1974², 134, énfasis original).

23 Según Mc 15, 15-24 antes de la burla se produce algo aún más grave, a saber, una flagelación del reo.

24 Dt 21, 1-9. Cfr. también Sal 26, 6; 73, 13; Carta de Aristeas 305-306. 
Mientras que en Mc 15, 15 (Mt 27,26) se afirma que «Pilato entregó a Jesús para

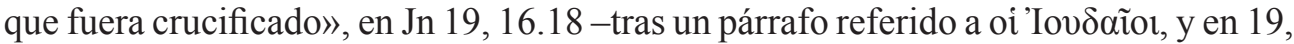
15 a oi ả $\rho \chi 1 \varepsilon \rho \varepsilon i ̃ \zeta-s e$ asevera: «Entonces, pues, se lo entregó para que fuera crucifica-

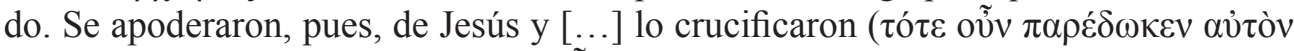
$\alpha$ Si bien la narrativa siguiente hace ver que quienes llevan a cabo la crucifixión son soldados (romanos), este pasaje da a entender que quienes ejecutan la pena son «los judíos»o «los sumos sacerdotes»-únicos sustantivos que sirven como antecedente al «ellos» $»^{25}$.

Una ulterior incongruencia en el Cuarto Evangelio estriba en que Pilato parece desconocer las implicaciones sediciosas del título «rey de los judíos», de tal modo que son las autoridades judías las que deben ilustrarle sobre ello: «Si lo sueltas, no eres amigo del César, pues todo el que se hace rey se opone al César» $(\mathrm{Jn} 19,12)$. La escena de las autoridades judías explicando este punto a un prefecto romano, chantajeándolo y amenazándolo implícitamente con delatar su deslealtad hacia el emperador si no ejecuta a un correligionario judío raya en lo increíble ${ }^{26}$.

Aunque sin pretensiones de exhaustividad, las consideraciones previas demuestran que la inconsistencia no se da en detalles nimios o aislados, sino que es omnipresente y afecta al núcleo mismo de la narración ${ }^{27}$. La falta de fiabilidad de una historia que presenta tal cúmulo de incongruencias es demasiado evidente, tanto más cuanto que -dejando aparte los aspectos sobrenaturales y legendarios ${ }^{28}$ - esas incongruencias convierten el curso de los acontecimientos en algo ininteligible ${ }^{29}$. De hecho, esta historia es estrambótica hasta tal punto que solo parece posible adoptar dos posiciones genuinamente críticas frente a ella. Una es considerar a los relatos pura ficción y negar toda posibilidad de usarlos como fuentes para una reconstrucción histórica ${ }^{30}$; tal posición desemboca con frecuencia en la negación de la historicidad del personaje

${ }^{25}$ Cfr. Winter $1974^{2}, 79-82$. Un fenómeno similar se halla en Lc 23, 25-26. Algunos exegetas confesionales han llegado al extremo de mantener la idea de que Jesús fue crucificado por los judíos; cfr. Bammel 1984, 439, 445 .

26 Algunos autores, empero, otorgan credibilidad histórica a Jn 19, 12-15; cfr. p. ej. Teja 1990, 23 (fiel a la ahistórica visión confesional, este autor se refiere también a Jesús como «el fundador del cristianismo»: ibid., 21).

${ }^{27}$ Hay más: la presentación de las autoridades judías escupiendo y golpeando a Jesús (Mc 14, 65) y de los sumos sacerdotes y escribas burlándose de un crucificado (Mc 15, 31-32) es asimismo improbable. Según Mc y Mt hay un proceso nocturno, mientras que según Lc y Jn hay solo un interrogatorio matutino, pero sin sentencia; según Mc y Mt los acontecimientos suceden en casa del sumo sacerdote, en Lc en el lugar de reunión del sanedrín, y en Jn en casa del suegro del sumo sacerdote.

28 Tinieblas cubren durante horas la tierra durante la crucifixión: Mc 15, 33 (y par.: Mt 27, 45; Lc 23, 44); velo del santuario que se rasga y resurrección de muchos cuerpos: Mt 27, 51-54 (cfr. Lc 23, 45); la mujer de Pilato le advierte que no actúe contra Jesús, porque ha sufrido en sueños por su causa: Mt 27, 19; Satanás entra en Judas Iscariote: Lc 22, 3 (Jn 13, 27); un ángel del cielo conforta a Jesús (Lc 22, 43); milagrosa curación de una oreja cortada (Lc 22, 51); quienes van a detener a Jesús caen en tierra cuando este les habla (Jn 18, 6).

${ }^{29}$ No en vano la muerte de Jesús es presentada a menudo como un «enigma» o un «misterio»; cfr. Green 2001, 88-89.

${ }^{30}$ Crossan 1995 considera los relatos no «history remembered» sino «prophecy historicized». 
central de los evangelios canónicos. Sin embargo, esta no es ciertamente la única conclusión que puede extraerse, y -como veremos- con toda probabilidad no la más solvente. Otra posibilidad, en efecto, consiste en considerar las incongruencias como el resultado de una edición de la tradición, y en sopesar la necesidad de proceder a la reconstrucción de una historia subyacente, que consista en discernir el material fiable con el que elaborar una historia plausible que no esté supeditada al desorientador hilo argumental de los relatos - una historia que originalmente debe de haber sido muy distinta ${ }^{31}$.

\section{UN PROCESO DE DESPOLITIZACIÓN}

Un objetivo principal de los evangelistas, íntimamente conectado con su propósito de promover la fe en Jesús como un ser sobrenatural, estriba en presentarlo como un sujeto único, maestro espiritual e individuo pacífico desconectado de los sucios asuntos de la política de Judea. Ahora bien, si no hay razones para dudar del carácter intensamente religioso del galileo, sí del intento realizado en las fuentes de eliminar de su figura la dimensión política ${ }^{32}$. El postulado de que tal despolitización se ha producido no es solo una conjetura genérica derivada de la a menudo inextricable conexión entre lo religioso y lo político en el judaísmo del Segundo Templo ${ }^{33}$, sino que obedece a razones específicas, que cabe extraer de la observación pausada de pasajes, escenas y motivos evangélicos. A continuación ofrezco algunos particularmente reveladores, y que ofrecen ulteriores ejemplos de incongruencias, extraídos de los relatos de la pasión o bien relacionados temáticamente con ellos.

\subsection{EPISODIOS QUE IMPLICAN EL USO DE VIOLENCIA}

Existen varias perícopas en los evangelios canónicos en las cuales Jesús y/o sus discípulos aparecen, de forma innegable, directamente asociados al ejercicio de la violencia o al uso de armas. Lo que mancomuna a estos textos no es solo su atmósfera

\footnotetext{
${ }^{31}$ La idea fue nítidamente expresada por Karl Kautsky: «Das ist in der Form, wie es hier steht, eine ganz sonderbare Geschichte, voll von Widersprüchen, die ursprünglich ganz anders gelautet haben muß» (Kautsky 1908, 387). La propia obra de este autor contiene un lúcido desvelamiento de muchas de las incongruencias de los relatos de la pasión (cf. Kautsky 1908, 384-392; 418-432).

${ }^{32} \mathrm{La}$ existencia de un proceso de despolitización en las fuentes es reconocida explícitamente incluso por autores confesionales; cfr. Davies 1994², 344. «In the known conditions under which primitive Christians lived in the Roman Empire it would be far easier to account for the toning down of apparently political features if the tradition originally contained such features, than to find reasons why they should be given enhanced importance in the development of a tradition originally innocent of them -or almost innocent, for nothing could eliminate from the record the fact that Jesus was crucified as 'King of the Jews'» (Dodd 1963, 215; cfr. ibid. 115).

${ }^{33}$ Piénsese, por ejemplo, en la inspiración teocrática de lo que Josefo llamó la «Cuarta Filosofía» (A. J. XVIII 2-23).
} 
violenta, sino también el hecho de que causan extrañeza cuando se leen con detenimiento, pues en su redacción actual carecen de sentido y lógica interna.

La escena de la -mal llamada- «purificación del Templo» es recogida tanto por los Sinópticos (que la sitúan en la visita de Jesús a Jerusalén ocurrida poco antes de su arresto y ejecución) como por el Evangelio de Juan (que la localiza casi al comienzo de su relato). Jesús es retratado irrumpiendo, solo, en el Templo en tiempo de Pascua y expulsando a los mercaderes sin que nadie se lo impida. Las perplejidades que suscitan estos relatos son múltiples. El Templo de Jerusalén era un recinto inmenso, visitado en Pascua por decenas de millares de peregrinos, y en el que había numerosos comerciantes efectuando un trabajo indispensable para la actividad sacrificial. Es ya difícil concebir a un solo hombre comportándose como lo hace Jesús, pero la idea de que pudo llevar a cabo su propósito sin encontrar resistencia (por parte de los mercaderes que ven interrumpido su negocio, de la guardia del Templo o incluso de los romanos) desafía toda capacidad de imaginación. Esto permite inferir que falta información relevante, y que el texto -en caso de reflejar efectivamente un hecho histórico- es o una magnificación de un incidente menor o la estilización de un suceso mucho más grave en el que estuvieron implicados un número considerable de seguidores de Jesús ${ }^{34}$.

Algo similar sucede con el conciso relato del episodio del arresto. Todos los evangelios narran la marcha nocturna de Jesús al Monte de los Olivos con sus discípulos pero no explican qué van a hacer alli ${ }^{35}$, ni por qué se necesita un contingente armado para apoderarse de un hombre supuestamente pacífico y rodeado tan solo de unos pocos seguidores inofensivos. Marcos y Mateo omiten información sobre la identidad de quien ataca con la espada con intenciones homicidas ${ }^{36}$, y ninguno de los evangelios se refiere a las reacciones del atacado ni del grupo al que pertenece. Tampoco se explica por qué Jesús - quien, como parece pretender Mateo, se opone por principio al uso de la violencia- había permitido que al menos algunos de sus discípulos tuvieran espadas. Si a ello se suma el ilógico esquematismo y lo dicho respecto al hecho de que el atacante no es arrestado y sí quien supuestamente opta por renunciar a la violencia, los relatos resultan virtualmente increíbles como descripciones de un hecho efectivamente acontecido ${ }^{37}$.

${ }^{34}$ Cfr. p. ej. Brandon 1967, 331-334, 338.

35 Mc 14, 32; Mt 26, 36; Lc 22, 39; Jn 18, 1-2 se refiere a un huerto (ки̃ $\pi \circ \varsigma)$. Sobre la significación escatológica y estratégica del Monte de los Olivos, cfr. Josefo, A. J. XX 167-172; B. J. II 261-263 (episodio del profeta egipcio).

${ }^{36}$ Mc 14, 47; Mt 26, 51. «Dieser Schwertschlag ist Gewaltanwendung mit möglicher Todesfolge» (Theissen 1989, 198).

${ }^{37}$ Otro hecho textual que da que pensar es que, en Marcos, la reacción de Jesús al uso de violencia brilla

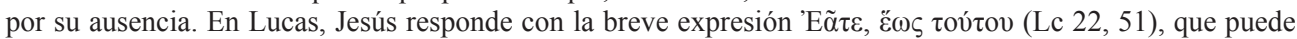
ser vertida como «Dejadlo, hasta aquí». Lo interesante es que se usa la segunda persona plural del presente de imperativo (de éó $\omega)$, lo que significa que -a diferencia de lo que ocurre en Mt 26, 52 y Jn 18, 11, donde se usa el singular- aquí Jesús ordena parar la acción a una pluralidad de discípulos, a pesar de que antes se dice que solo uno había sacado la espada. Al igual que ocurre con Lc 22, 49, esto puede ser un indicio de que -como algunos estudiosos han sugerido- la escena de Getsemaní es la estilización de un encuentro armado mucho más violento de lo que los evangelistas estaban dispuestos a reconocer abiertamente. 
Un tercer ejemplo es una escena que forma parte del material especial (Sonder$g u t)$ de Lucas. En este evangelio, se describe a Jesús diciendo a sus discípulos: «"Mas ahora quien tenga bolsa tómela; asimismo también alforja; y quien no tenga espada venda su manto y se compre una. Porque os digo que tiene que cumplirse en mí lo que está escrito: 'Y fue contado entre los delincuentes'. Pues lo que a mí se refiere toca a su fin'. Ellos dijeron: 'Señor, mira, aquí hay dos espadas'. Él les dijo: 'Es suficiente'» (Lc 22, 36-38). Este pasaje suscita, de nuevo, muchas preguntas que no hallan respuesta. ¿Por qué Jesús insta a aquellos de sus discípulos que no tienen espada -lo que presupone que algunos sí la tenían- a adquirir una, si enseguida parece declarar que dos bastan ${ }^{38}$ ? ¿Y es este realmente el sentido del texto? Según Lc 22, 49, los discípulos preguntan: «Señor, ¿herimos con la espada?», lo que presupone que muchos $-\mathrm{o}$ todos- están $\operatorname{armados}^{39}$. $\mathrm{Y}$ aun suponiendo que fueran dos espadas, ¿para qué eran necesarias? ${ }^{40}$ ¿Cuál es la conexión entre este episodio y el violento incidente del arresto ${ }^{41}$ Resulta virtualmente imposible aceptar que el pasaje no ha sido obscurecido o truncado.

Ninguno de los pasajes mencionados tiene, por consiguiente, genuino sentido en su redacción actual. Ninguno de ellos es creíble, sea como diálogos o episodios tomados de la vida real. La razón parece no ser otra que la de que han sufrido un severo proceso de edición: en todos ellos falta información relevante y es precisamente esta ausencia lo que da cuenta de su carácter incoherente.

\subsection{ECCE HOMINES: JESÚS ENTRE LOS INSURGENTES}

Los episodios examinados están lejos de ser los únicos que en los relatos de la pasión causan desazón a una mirada atenta a la plausibilidad histórica. La escena misma de la crucifixión constituye un ejemplo conspicuo de este mismo fenómeno. Según todos los evangelios, Jesús no fue crucificado solo, sino con otros dos hombres ${ }^{42}$. En este caso no parece haber razones serias para cuestionar la historicidad de la información, pues el carácter infamante del suplicio y la dimensión sediciosa que traiciona en el condenado hacen improbable que los cristianos hubieran inventado el dato si no hubiera habido constancia inequívoca de él; además, es también improbable que la escena de una crucifixión colectiva haya sido excogitada, pues contradice la tenden-

\footnotetext{
38 Además, la instrucción a sus discípulos se imparte, al parecer, solo para cumplir una profecía. Las palabras de Jesús en Lucas son abstrusas en su concisión. «They are probably Luke's invention and are intended to abate the implication of Jesus' arming of his disciples (xxii.36-8)» (Brandon 1967, 317 n. 4).

39 Para un reciente argumento en favor del carácter armado del grupo de Jesús, cfr. Martin 2014.

40 «The passage is in fact the despair of commentators» (Beare 1962, 228).

41 «Le rapprochement est plus que singulier de ce conseil avec l'emploi réel de l'épée au mont des Oliviers [...] le fait d'une résistance opposée par les disciples à l'arrestation de Jésus paraît assez consistante, et aussi leur prompte déroute; il serait donc possible également, bien que les interprètes n'aient guère songé à l'admettre, que notre évangeliste ait travaillé sur une source où la résistance des disciples avait été prévue et même encouragée par Jésus» (Loisy 1924, 522-523).

${ }^{42}$ Mc 15, 27.32; Jn 19, 18. No puede descartarse que el número de crucificados fuera mayor.
} 
cia de la tradición a singularizar a Jesús ${ }^{43}$. Al igual que las crucifixiones ordenadas por el legado de Siria Quintilio Varo, y más tarde por los procuradores de Judea, la del Gólgota fue una ejecución colectiva. Ahora bien, caben fundadas sospechas de que los relatos han experimentado una considerable reelaboración editorial, en primer lugar porque presentan a uno de los crucificados como si no tuviera relación alguna con los demás.

Aunque la tradición y/o los autores de los evangelios no parecen haber estado interesados en la identidad de los hombres crucificados junto a Jesús -y es esta una segunda causa de perplejidad-, el hecho de que Marcos y Mateo se refieran a ellos como $\lambda \eta n \sigma \tau \alpha i ́$ proporciona una elocuente pista, si bien esta debe ser críticamente considerada. En efecto, $\lambda \eta \emptyset \sigma \tau$ ' significa «bandido»o «bandolero», pero hay razones muy poderosas para creer que esta caracterización no es fiable, y por tanto que los crucificados con Jesús no eran en modo alguno salteadores de caminos. Para empezar, el robo no era considerado habitualmente en el Imperio Romano merecedor de la pena de crucifixión; más concretamente, durante el período de control romano de Judea desde el 63 al menos hasta la Guerra Judía, todos los testimonios disponibles indican que la crucifixión se aplicó únicamente a rebeldes políticos y sus

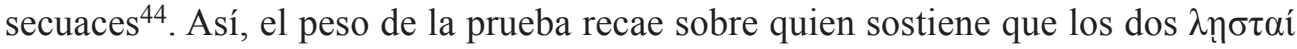
no eran insurgentes.

En segundo lugar, que $\lambda \eta \emptyset \sigma \tau \alpha i ́$ es un término derogatorio susceptible de ser usado para referirse a los revolucionarios antirromanos lo demuestra otra fuente del s. I e.c. Los judíos a los que Flavio Josefo denomina $\lambda \eta ฺ \sigma \tau \alpha i ́$, que atacan la torre Antonia tras un asedio y matan a su guarnición no eran salteadores, como no lo eran aquellos a quienes Menajén -el descendiente de Judas el Galileo- proporcionó armas tras hacerse con el arsenal de Masada, ni quienes mataron al sumo sacerdote Ananías en Jerusalén ${ }^{45}$. Tampoco eran bandidos quienes atacaron a los romanos durante el asedio de Jerusalén por parte del legado de Siria Cestio Galo, ni los que tomaron Masada, ni los que resistieron a los legionarios en las fortalezas de Herodión y Maqueronte ${ }^{46}$. En estos y otros casos Josefo usa el término $\lambda \eta \eta \sigma \tau \alpha i ́$, pero a ningún historiador cabal se le ocurriría contar la historia de la Guerra Judía aseverando que quienes se opusieron a Roma eran delincuentes comunes. De hecho, resulta claro que el antiguo comandante de Galilea usó a menudo el término $\lambda \eta ̣ \sigma \tau \alpha i ́$ de modo despectivo con el propósito apologético de silenciar los móviles religioso-nacionalistas de muchos de quienes se opusieron a la dominación romana, y por tanto de exculpar de la responsabilidad de la guerra a la facción sacerdotal a la que él mismo pertenecía y, por extensión, a la generalidad de la nación; con este fin, retrató a menudo a los insurgentes como simples «bandidos», es decir, como un colectivo marginal y desconectado de cualesquiera

${ }^{43}$ Cfr. Légasse 1994, 144.

${ }^{44}$ Cfr. Kuhn 1982, 724.

${ }^{45}$ Cfr. respectivamente B. J. II 420, 434, 441.

${ }^{46}$ Cfr. respectivamente B. J. II 541 (con referencias previas a los $\sigma \tau \alpha \sigma \iota \alpha \sigma \tau \alpha i ́ ;$ cfr. B. J. II 534, 538) y B. J. IV 504, 555. 
ideales dotados de dignidad espiritual y moral ${ }^{47}$. Dejar este aspecto inexplicado -no mostrar el sesgo del autor- sería intelectualmente irresponsable.

Ahora bien, todo indica que los autores de los evangelios canónicos fueron impulsados asimismo por intereses apologéticos. La necesidad de reinterpretar la crucifixión de Jesús no como un fracaso - por tanto, como algo diferente del desenlace de un episodio de resistencia antirromana-, así como el deseo de presentar a las comunidades nazarenas desconectadas de toda oposición al Imperio y contribuir de ese modo a su supervivencia tras la destrucción de Jerusalén en 70 e.c. constituyen tendencias obvias de estos escritos. A esta luz puede entenderse mejor que, al igual

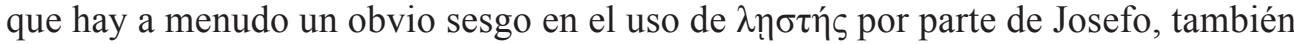
lo hay en el uso del término en el evangelio de Marcos, a saber, el interés por desactivar cualquier tentación de conectar a Jesús con elementos hostiles al Imperio. Presentando a los crucificados como «bandidos», esa tentación queda eliminada ${ }^{48}$. Otro dato corrobora que en el uso del término ha tenido lugar un proceso de despo-

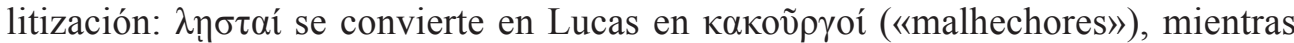
que el Cuarto Evangelio opta por obviar el término y hablar simplemente de «otros $\operatorname{dos} \gg{ }^{49}$.

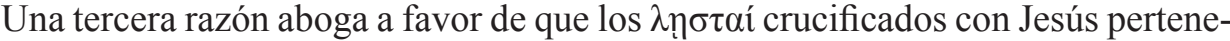
cían a la insurgencia antirromana, a saber, las noticias que revelan una situación conflictiva de resistencia. El evangelio de Marcos contiene una referencia a una reciente

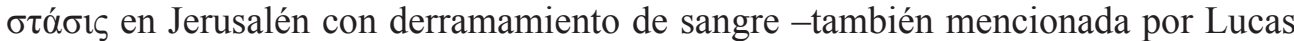
(Lc 23, 19)- y a los $\sigma \tau \alpha \sigma 1 \alpha \sigma \tau \alpha i ́$ que habían participado en ella (Mc 15, 7). ${ }^{50}$ Lc 13, 1 menciona a un grupo de galileos «cuya sangre había mezclado Pilato con la de sus sacrificios ${ }^{51}$. De estos episodios cabe inferir la existencia de una atmósfera sediciosa en la época y el lugar en que se produce la crucifixión colectiva del Gólgota.

La explicación más sencilla y plausible para el hecho de que los romanos crucificaran juntos a un grupo de hombres es que estos estaban relacionados. Además, la noticia de que Jesús fue crucificado en posición central ${ }^{52}$ parece indicar que el prefecto lo consideró el cabecilla del grupo - una interpretación que se ve respaldada por la noticia sobre el titulus crucis, «rey de los judíos»-53. Los relatos evangélicos,

\footnotetext{
47 Josefo no es coherente en esto, pues puso de relieve el carácter religioso de la «Cuarta Filosofía».

${ }^{48} \mathrm{Mc}$ y Mt ponen en boca de Jesús una frase que niega tan indirecta como enfáticamente tal posible identificación: «¡Como contra un bandido ( $\dot{\varsigma} \varsigma \dot{\varepsilon} \pi \grave{\imath} \lambda \eta \sigma \tau \eta ́ v)$ habéis salido con espadas y bastones a prenderme!» (Mc 14, 48; Mt. 26, 55).

${ }^{49}$ Samuel Brandon se preguntó si el silencio del Cuarto Evangelio podría indicar que el autor sabía «that these two crucified with Jesus were his followers?» (Brandon 1967, 351, n. 1). Nótese que Jn 18, 40 usa el término

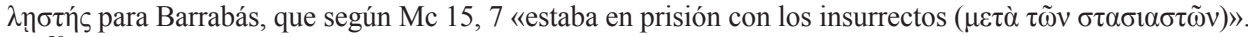

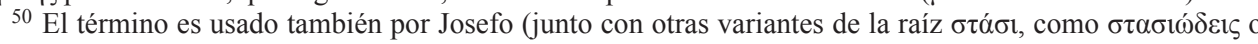

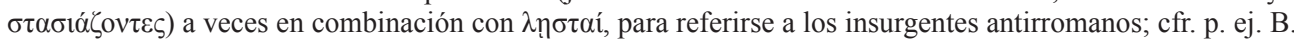
J. I 10.

${ }^{51}$ Sobre el carácter sedicioso de estos galileos, cfr. Blinzler 1957.

${ }^{52}$ Así lo indican Mc 15, 27 y Jn 19, 18.

${ }^{53}$ La crucifixión romana tenía un sentido paródico, y la ejecución del cabecilla en medio del grupo habría reflejado su supuesta jerarquía; cfr. Marcus 2006.
} 
sin embargo, intentan decir algo muy diferente. Según ellos, a pesar de que Jesús fue crucificado con y entre otros hombres, estos nada tenían que ver con él. Tanto Marcos como Mateo afirman que «le ultrajaban» ${ }^{54}$. El relato lucano va más allá, aunque a costa de contradecir parcialmente a los otros evangelistas; uno de los crucificados increpa a Jesús (Lc 23, 39), mientras el otro, a su vez, reconviene a su compañero: «¿Ni siquiera temes tú a Dios, estando en el mismo suplicio? Nosotros lo estamos justamente, pues recibimos el adecuado pago de lo que hicimos; mas este nada malo ha hecho» (Lc 23, 40-41). El evangelista busca así postular una abismal diferencia

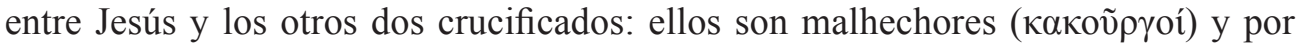
ello merecidamente castigados, mientras que Jesús es una víctima inocente.

Si esta descripción de los acontecimientos resulta ya harto sospechosa de estar dictada por intereses apologéticos, no es lo único que siembra dudas sobre su credibilidad $^{55}$. En efecto, los evangelistas dejan en la penumbra demasiada información relevante: ¿Quiénes eran esos individuos, y de dónde provenían? ¿Cuándo habían sido arrestados, y por quién? ¿Por qué razón habían sido crucificados? ¿Y por qué lo habían sido junto a Jesús, y cada uno a un lado de él, si nada tenían que ver con él? Aunque las deficiencias de la memoria deben de haber jugado un papel en la tradición que produjo los evangelios, es difícil creer que originalmente no se hubieran conocido al menos algunas de las respuestas a estas preguntas tan elementales sobre una situación crucial en la vida de Jesús. Todo indica que información esencial -seriamente embarazosa para la conciencia cristiana- ha sido cancelada en la tradición, haciendo confuso el resultado final. Una vez más, un proceso de despolitización -

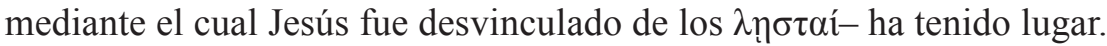

\subsection{LA PRETENSIÓN REGIA DE JESÚS, O LA VOLUNTAD DE USURPACIÓN}

Como hemos visto, de los relatos se deduce que los romanos procedieron a una crucifixión colectiva, y que en ella Jesús parece haber ocupado un puesto central, debido probablemente a una reivindicación de realeza. Si hay una pretensión que tendría un sentido inequívocamente político, sería el intento por parte de un provincial de usurpar el imperium al prefecto -y, en última instancia, al emperador-proclamándose rey, tal como había sucedido tras la muerte de Herodes y sucedería durante la Guerra Judía ${ }^{56}$. Pues bien, aunque en las fuentes Jesús no es descrito de modo

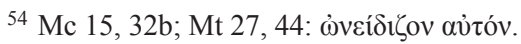

55 De hecho, diversos estudiosos han conjeturado que esos hombres deben de haber sido seguidores de Jesús, o al menos haber estado conectados ideológicamente a él; cfr. Eisler 1929-1930, II, 525-526; Brandon 1968, 103; Maccoby 1973, 218; Montserrat Torrents 2007, 142-3. Para una detallada argumentación en este sentido, cfr. Bermejo 2013a.

56 Según Josefo, los dirigentes de las revueltas que estallaron en Galilea, Perea y Judea tras la muerte de Herodes, aspiraron a la realeza; cfr. B.J. II 56-65; A. J. XVII 271-81 (Judas, Simón, Atronges); cfr. A. J. XVII 285. La obvia naturaleza sediciosa de la pretensión se explicita en Jn 19, 12 y Hch 17, 7 («Y todos estos obran contra los edictos del César, diciendo que hay otro rey, Jesús»).
} 
consistente como «rey», hay toda una serie de indicios en el sentido de que tras el titulus -cuya historicidad es altamente probable $-{ }^{57}$ parece haber habido una efectiva aspiración a la realeza por su parte.

La expresión «rey de los judíos» aparece de modo enfático en el interrogatorio ante Pilato y en la narrativa siguiente (Mc 15, 2.9.12.18.26.32). Según Mc 15, 1620 (cfr. Jn 19, 1-5), Jesús es objeto de una parodia de epifanía regia por parte de los soldados, que incluye ponerle una vestidura púrpura, una corona de espinas y prosternarse ante él como una muestra burlona de vasallaje ${ }^{58}$. Además, la descripción de la entrada en Jerusalén está infestada de motivos regios ${ }^{59}$.

Lo que es aún más elocuente, los propios discípulos de Jesús, y del considerado círculo de los más íntimos, Santiago y Juan, presuponen el rango regio de Jesús en su petición de sentarse a su lado en los puestos de mayor honor, cuando fuese entronizado como rey de la nueva edad escatológica (cfr. Mc 10, 35-40). El mismo estatus está implícito en los relatos de los evangelios sinópticos, cada vez que Jesús es llamado «hijo de David» ${ }^{60}$.

Existen otros textos, numerosos, que asumen el estatuto regio de Jesús. Así, por ejemplo, en Lc 22, 29-30, una contienda entre los discípulos es zanjada por él mismo con estas palabras: «Yo dispongo a favor vuestro, como dispuso a mi favor mi padre,

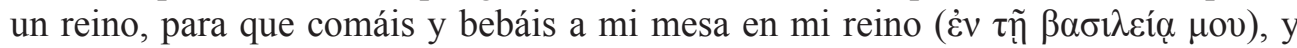
os sentaréis en tronos para juzgar a las doce tribus de Israel». También en el Cuarto Evangelio se encuentra abundante material pertinente ${ }^{61}$.

No es necesario argumentar detalladamente en pro de la autenticidad de cada uno de estos pasajes ${ }^{62}$. Lo que resulta instructivo es que, a pesar de que Jesús no es presentado de manera clara y sistemática como aspirante a la realeza, la idea de su pretensión regia emerge con llamativa frecuencia en los evangelios, por lo que es apenas creíble que el motivo haya sido inventado o que su recurrencia sea el fruto de una mera casualidad. Hay, pues, serias razones para creer que el titulus crucis refleja la pretensión efectiva de Jesús de ser -o estar llamado a convertirse en- rey de Israel. Esto hace, si cabe, aún más comprensible que haya sido considerado por la autoridad romana auctor seditionis ${ }^{63}$. Todo indica que el carácter embarazoso de la pretensión

\footnotetext{
57 Véase la detallada argumentación en Allison 2010, 233-240.

${ }^{58}$ Una parodia similar con ocasión de la visita de Agripa a Alejandría se narra en Filón, In Flaccum 6, 36-41.

${ }^{59}$ P. ej. extensión de vestiduras y ramajes al paso de Jesús, uso de palmas, aclamaciones, etc. Sobre la significación nacionalista de algunos de estos detalles, cfr. Blenkinsopp 1961; Farmer 1956, 125-158.

${ }^{60}$ Mc 10, 47-48; 12, 35; Mt 12, 23; 15, 22.

${ }^{61}$ Cfr. Jn 1,$49 ; 6,15 ; 12,13.15 ; 18,33.36-39 ; 19,3.12-21$. La típica objeción según la cual la noticia de que Jesús, sabedor del deseo de una multitud de hacerle rey, se aleja, demuestra su desconexión con respecto a aspiraciones políticas, carece de fuerza de convicción. Por una parte, la iniciativa popular tiene más sentido si algo en el discurso y/o la acción de Jesús la propicia; por otra, la retirada de Jesús -si hay que dar crédito a la narración- podría interpretarse como provisional y estratégica, a fortiori a la luz del resto del material.

${ }^{62}$ Sobre los patrones de recurrencia como poderosos indicios de historicidad, cfr. Allison 2010, 10-30 Bermejo 2012.

${ }^{63}$ «Jesus, when he imagined the future, saw himself ruling on God's behalf, saw himself being like the worthy Israelite and Jewish kings in the Bible. God's kingdom was his kingdom» (Allison 2010, 246-247).
} 
llevó a los evangelistas a contar una historia en la que la coherencia del motivo regio dejó de ser fácilmente detectable.

\subsection{LA LÓGICA SUBYACENTE Y LAS HIPÓTESIS ALTERNATIVAS}

El análisis de perícopas, escenas y motivos efectuado en esta sección corrobora lo ya señalado sobre el carácter incongruente de los relatos de la pasión, pero nos permite entender ahora la razón de esa incongruencia. En efecto, hay un Leit-motiv que conecta los pasajes examinados: en todos ellos Jesús aparece en un contexto de violencia (incidente del templo, episodio del arresto, diálogo sobre las espadas) y/o de resistencia activa antirromana (escena de crucifixión colectiva, pretensión regia). Todos ellos se refieren a momentos o aspectos decisivos en la vida del personaje, cuyo conocimiento permitiría arrojar mucha luz sobre su identidad, el sentido de su presencia en Jerusalén y las razones de su ejecución. Dado que la narración debía contener originalmente información comprometedora, no sorprende que haya tenido lugar una edición del material.

Es una conjetura razonable que la causa de la edición se halle en el carácter de los episodios analizados: todo aquello que permite vislumbrar una conexión de Jesús con ideología o actividad antirromana ha sido reelaborado ${ }^{64}$, pero lo ha sido siempre en el mismo sentido, a saber, haciendo inocuo, confuso o equivoco lo que originalmente debe de haber tenido una significación clara y definida. Esos pasajes en los que se detecta una conexión entre Jesús y la violencia o la resistencia al Imperio han sido convertidos en algo abstruso, como si los autores o la tradición hubieran querido impedir o dificultar la percepción clara de tal conexión ${ }^{65}$. Es precisamente el carácter sistemático de esa edición lo que permite detectar la existencia de una tendencia subyacente y su propósito ${ }^{66}$. A la omnipresente incongruencia subyace por tanto una lógica precisa, de tal modo que podría observarse también aquí lo que, en Hamlet, Polonio dice para sí al escuchar con atención las palabras del príncipe de Dinamarca, a saber, que hay un método tras su aparente locura.

Hay, pues, una lógica subyacente que ha generado la falta de lógica de los relatos actuales. Las circunstancias históricas que la explican han sido elucidadas a menu$\mathrm{do}^{67}$ : la creciente separación de la secta nazarena respecto a su matriz judía, junto

\footnotetext{
${ }^{64}$ Utilizo «edición», no «manipulación», pues no debe presuponerse una tergiversación consciente. Existen no pocos casos de falsificaciones en la historia cristiana primitiva (cfr. p. ej. Ehrman 2013), pero el proceso de alteración de la tradición evangélica no precisa necesariamente de una explicación en términos crasos: las formas del autoengaño, aunque no inescrutables, son numerosas, y muchas de ellas se producen de forma inconsciente.

65 «Tatsächlich sind sie, wenn auch nicht einhellig gestrichen, so doch im Lauf der Zeit so weit als möglich abgetönt worden» (Eisler 1929-1930, II, 254); «When we take a closer look at the Gospel accounts [...], we find that the facts are not so much suppressed as disguised» (Maccoby 1973, 166).

66 «Nor is this merely the incoherence of an imperfectly remembered event; the incoherence is the result of dynamic factors -it is tendentiously incoherent» (Carmichael 1982, 41).

${ }^{67}$ Cfr. p. ej. Winter 1974; Brandon 1967, 221-321.
} 
con la necesidad apologética de congraciarse con el poder romano en un contexto de catástrofe del judaísmo tras la destrucción del Templo de Jerusalén (y de la posible génesis del evangelio de Marcos en Roma) ocasionó la necesidad de relatar la muerte de Jesús amortiguando la responsabilidad en ella del Imperio e inventando o magnificando la de las autoridades judías, pero también cancelando u oscureciendo en lo posible la dimensión antirromana e insurgente de la personalidad y la actividad de Jesús y de sus discípulos. Lo que estaba en juego era nada menos que la supervivencia de las comunidades cristianas primitivas en el Imperio Romano. Esta necesidad se incrementó por razones estrictamente teológicas: el Cristo divino, salvador de la humanidad, no podía estar implicado en particularismos nacionales judíos, menos aún de naturaleza revolucionaria y violenta ${ }^{68}$. Esto implicó la eliminación, por parte de los evangelistas y de los transmisores de la tradición, de mucho material, así como de las conexiones que originalmente habrían hecho inteligible el curso de los acontecimientos ${ }^{69}$.

Este procedimiento, sin embargo, no implicó la desaparición de la totalidad del material embarazoso. Aunque tuvo lugar una edición del material convertido en incómodo por las nuevas circunstancias históricas, esta fue efectuada de modo inconsistente -lo que explica el hecho de que aquel reaparezca aquí y allá en las fuentes, si bien solo en forma de disiecta membra- ${ }^{70}$. Tales inconsistencias subvierten la intención de los autores de los relatos evangélicos, yendo más allá de esta y revelando lo que se habría preferido no manifestar ${ }^{71}$.

68 Brandon 1967, 320.

${ }^{69}$ El proceso no implicó solo la eliminación de material relevante, sino también su interpretación mediante su reformulación o añadidos. Por ejemplo, Lc 9, 23 parece buscar desactivar las espinosas implicaciones de un Jesús que enfrenta a sus seguidores a la posibilidad de arrostrar la cruz $(\mathrm{Mc} 8,34)$ insertando la expresión $\kappa \alpha \theta^{\prime}$ $\grave{\eta} \mu \varepsilon ́ \rho \alpha \nu$ («diariamente»), dando un sentido metafórico a una realidad tan concreta y de significación sediciosa como la «cruz».

70 Diversas razones explican esta inconsistencia. El hecho de que los autores posteriores a Marcos escribieran en circunstancias en que no estaban tan condicionados por la sombra de la Guerra Judía es una de ellas. Otra es el hecho de que todos ellos estaban enfrentados a intereses conflictivos: mantener la fidelidad a la tradición recibida sobre el maestro venerado, y al mismo tiempo ponerse a salvo de críticas hostiles. Deben tenerse en cuenta igualmente las enseñanzas del psicoanálisis sobre la mecánica de la represión y el retorno de lo reprimido (el sujeto dice a menudo más de -y algo diferente a- lo que quiere decir), así como las de la deconstrucción sobre las tensiones internas del discurso.

${ }^{71}$ Un análisis de los pasajes relativos a los crucificados con Jesús permite deconstruir las intenciones de los evangelistas (y ello con total independencia de lo que se opine sobre la historicidad del relato). Así, las palabras del crucificado que recrimina a Jesús y le reta a salvarle en Lc 23, 39 solo tienen sentido si -en contra de lo que Lc pretende- ese sujeto supone que no es un simple «malhechor» (que no tendría razón alguna para esperar ser salvado por el Mesías), sino alguien merecedor de ser salvado; pero esto presupone que ha sido condenado por una acción de resistencia (religiosamente inspirada) contra el opresor romano; cfr. Eisler 1929-1930, II, 526. Más interesante aún es lo que se deduce de las palabras del otro crucificado. Este, por un lado, afirma que, a diferencia de él y de su otro compañero, Jesús es inocente de todo crimen. Sin embargo, a continuación pide

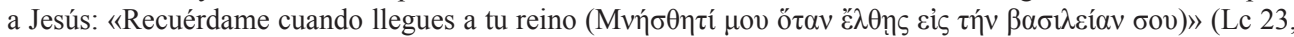
42). Tanto la petición como su formulación presuponen la creencia en la veracidad de la pretensión de Jesús a la realeza (lo que, a diferencia de lo que pretende el evangelista, implica que este hombre es un seguidor de Jesús); ahora bien, tal pretensión regia es precisamente el cargo, inequívocamente sedicioso, por el que Jesús ha sido acusado y sentenciado por la autoridad romana. Esto implica que - a diferencia de lo que él mismo 
Solo cuando se repara en el verdadero alcance de la incongruencia de los relatos, y en que esta se explica a la luz de un -muy comprensible- proceso de despolitización, es posible construir una historia alternativa a la narración evangélica con suficientes garantías de que no se está incurriendo en mera eiségesis o arbitraria especulación. A su vez, esto implica asimismo que solo es posible otorgar sentido a los relatos si se presupone una historia subyacente sensiblemente distinta. La obvia inferencia de que la historia original de Jesús debe de haber poseído una decisiva dimensión política se ve corroborada y adquiere cuerpo mediante la detección del abundante material de naturaleza revolucionaria cuya presencia cabe rastrear todavía en los evangelios -comenzando por los testimonios sobre el titulus crucis y por la posición central de Jesús en una crucifixión colectiva de $\lambda \eta\rceil \sigma \tau \alpha i ́-$, lo que permite atar los cabos sueltos y concluir con un altísimo grado de probabilidad histórica que, al igual que los seguidores de la Cuarta Filosofía, aunque Jesús fue un sujeto religiosamente inspirado estuvo implicado en la resistencia antirromana ${ }^{72}$. Esta hipótesis permite explicar de manera sencilla y unitaria todos los problemas textuales y lógicos que nos hemos encontrado hasta el momento, y disipar las perplejidades derivadas de ellos ${ }^{73}$. Así pues, y a diferencia de lo que se suele asumir, la carga de la prueba no recae en quien quiera demostrar la implicación de Jesús en la resistencia antirromana, sino en quien pretenda negarla ${ }^{74}$.

pretende, y a diferencia de lo que pretende el evangelista- Jesús ha sido justamente condenado. Para una deconstrucción detenida de estos pasajes, cfr. Bermejo 2013a, 138-141.

${ }^{72}$ Así lo han puesto de relieve, entre otros, H. S. Reimarus, K. Kautsky, R. Eisler, S.G.F. Brandon, H. Maccoby y G. Buchanan. Cfr. Puente Ojea 1974, 108-122 y 200-213; Montserrat Torrents 2007; Piñero 2010; Bermejo 2014b; Bermejo 2015a. Recientemente se ha mostrado que un análisis crítico del Testimonium Flavianum, el texto de Josefo sobre Jesús y los cristianos, parece refrendar esta reconstrucción; cfr. Bermejo 2014a.

${ }^{73}$ Dado que es imposible estar seguro del alcance exacto de la edición de la historia efectuada por la tradición evangélica, hay al menos dos variantes de la hipótesis: una según la cual Jesús llevó a cabo de manera consistente actividad de tipo militar (así Eisler, Montserrat...), otra según la cual sus actos violentos se limitaron a una fase final en la que él y su grupo esperaban la manifestación definitiva de Dios y consideraron necesaria la sinergia humano-divina - de modo parecido a lo que se presupone en el Rollo de la Guerra de Qumrán (así Maccoby, Martin...)-. Para una respuesta a las habituales objeciones sobre la hipótesis general, cfr. Bermejo 2013b.

${ }^{74}$ Esto permite considerar insuficientemente críticas las conclusiones aporéticas de algunos estudiosos: «No es posible demostrar que Jesús fuese un mártir de la revolución, pero más infundado es convertirlo en un personaje sublime, distraído de la realidad y de los antagonismos acuciantes, sociales y políticos, en los que él mismo perdió la vida. El problema parece insoluble, porque ni se puede aceptar el retrato que los evangelios transmiten de Jesús ni podemos recuperar su figura histórica prescindiendo de ellos» (Fernández Ubiña 2000, 166). Formulaciones como esta resultan falaces, pues ningún estudioso serio propone recuperar la figura de Jesús prescindiendo de los evangelios, sino discernir en estos lo que parece fiable en virtud de diversos criterios de lo que parece construcción ideológica y anacronismo. Por lo demás, si bien una frase como «no es posible demostrar que...» es -si se entiende como referida a una demostración apodíctica, y dada la naturaleza de las fuentes disponibles- indiscernible de un truismo, lo cierto es que la hipótesis de que Jesús estuvo implicado en la resistencia antirromana goza, en virtud de su simplicidad y su capacidad explicativa, de una considerable superioridad epistémica sobre sus alternativas, lo que la hace con mucho preferible a ellas. Hablar de «problema insoluble» es, en estas circunstancias, del todo injustificado y desorientador. 


\section{LA PERSISTENCIA DE LA FICCIÓN EN LA ACADEMIA}

Dado que el análisis crítico de las fuentes evangélicas se ha producido desde el Renacimiento, y que la investigación independiente sobre la figura de Jesús comenzada hace varios siglos - a pesar de las comprensibles resistencias con que se ha topado tal tarea en ciertos ámbitos- se ha proseguido hasta la actualidad, cabría esperar que en el s. XXI, en las obras escritas por historiadores, se hubiese tomado seriamente en cuenta de una vez por todas la magnitud de las distorsiones operadas en la tradición, y los resultados derivados del cuestionamiento de esta hubieran sido asumidos en una reconstrucción plausible del personaje. Estas elementales expectativas, sin embargo, se ven defraudadas una y otra vez. El tratamiento de la figura de Jesús, sea en monografías, sea en los capítulos correspondientes de muchas de las historias del cristianismo publicadas en la actualidad, adolece de gravísimas deficiencias, en la medida en que sus autores siguen reproduciendo elementos nucleares de la ficción evangélica. A continuación demostraré este aserto, trayendo a colación algunas obras recientes sobre el personaje ${ }^{75}$.

\section{1. ¿FUEJESÚSCRUCIFICADOENTREDOS «LADRONES»/«DELINCUENTES COMUNES»?}

En 2009, en la prestigiosa colección Wissenschaftliche Untersuchungen zum Neuen Testament de la editorial Mohr Siebeck, se publicó una obra colectiva titulada Key Events in the Life of the Historical Jesus ${ }^{76}$. En ella, uno de sus coeditores, Robert L. Webb -bien conocido por sus estudios sobre judaísmo palestino y como editor del Journal for the Study of the Historical Jesus- colaboró con tres extensos capítulos, uno de los cuales («The Roman Examination and Crucifixion of Jesus: Their Historicity and Implications») está dedicado a la crucifixión del predicador galileo ${ }^{77}$. No es este el lugar para una evaluación detenida -baste señalar que la cuestión esencial del carácter colectivo de esa crucifixión no merece en ese trabajo la menor reflexión-, pues aquí me interesa enfatizar un solo aspecto. Webb se refiere así a los hombres crucificados con Jesús:

The statement of crucifixion is found in all four canonical Gospels. In Mark and Matthew the statement of Jesus' crucifixion and the mention of two thieves are separate from one another (Mark 15:24, $27=$ Matt 27:35, 38), and the other subjects of crucifixion are identified as $\lambda \eta \emptyset \sigma \tau \alpha i\left(\langle\text { robbers } »)^{78}\right.$

\footnotetext{
${ }^{75}$ Una crítica cabal de las distorsiones en este campo requeriría la redacción de un volumen. Aquí me limito a unos pocos ejemplos, procedentes de monografías o de historias del cristianismo, tanto españolas como extranjeras.

76 Bock y Webb 2009. El volumen tiene 931 páginas y está diseñado como obra de referencia.

77 Bock y Webb 2009, 669-773.

${ }^{78}$ Bock y Webb, 2009, 684, n. 42.
} 
El autor utiliza dos términos corrientes en la lengua inglesa para «ladrones», thieves y robbers -Jesús, pues, habría sido crucificado entre dos ladrones-, y ello a pesar de que el término griego que traduce al menos el primero de esos términos

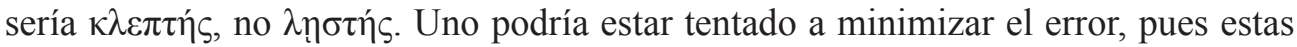
versiones se hallan, por así decirlo, ya instaladas en el hardware de la conciencia occidental: muchas Biblias traducen $\lambda \eta\rceil \sigma \tau \alpha i ́$ como «ladrones» ${ }^{79}$, y esta designación resulta universalmente familiar. No obstante, este hecho no puede ser utilizado en descargo de quien aspira a efectuar una reconstrucción histórica caracterizada por el rigor y la acribia filológica.

En el mismo año de aparición de Key Events, se publicó otra ambiciosa obra cuyo provocador subtítulo no debería llamar a engaño: A History of Christianity: the First Three Thousand Years ${ }^{80}$. Su autor, Diarmaid MacCulloch, es profesor de Historia de la Iglesia en Oxford, miembro de la Royal Historical Society, especialista reconocido en el período de los Tudor y coeditor de la revista Journal of Ecclesiastical History. A pesar de que es una obra generalista, A History of Christianity impresiona por su erudición y sus amplias miras, que van más allá de los típicos enfoques eurocéntricos. Es precisamente la indudable calidad de este volumen lo que hace tanto más significativo que, cuando aborda el hecho central en torno al que pivota el Nuevo Testamento y con ello el cristianismo, MacCulloch incurra en un error tan atávico como garrafal. En efecto, al referirse a la muerte en cruz de Jesús, el historiador escribe que este fue

put on trial and executed along with two common criminals (juzgado y ejecutado junto con dos delincuentes comunes ${ }^{81}$

Nótese que, al hablar de «common criminals», el autor no está ofreciendo a sus lectores una traducción, ni simplemente parafraseando el texto bíblico, sino efectuando una afirmación como historiador. Ahora bien, dado que, como he argumentado con anterioridad, todo indica que los $\lambda \eta \emptyset \tau \alpha i ́$ crucificados con Jesús deben de haber estado -quizás inspirados por ideales religiosos- implicados en resistencia antirromana, su caracterización como «delincuentes comunes» es una afirmación tan desorientadora como afirmar que eran $\left\langle\right.$ ladrones ${ }^{82}$. Tales designaciones descuidan enteramente no

\footnotetext{
${ }^{79}$ La King James Version tiene «thieves», y la Revised Standard Version «robbers». En España, la Biblia del Oso de Casiodoro de Reina, publicada en Basilea en 1569, tiene «ladrones» (al igual que la versión revisada de Cipriano de Valera). «Ladrones» es la versión que se encuentra aún hoy en no pocas versiones españolas -incluyendo la llamada «Biblia Interconfesional» y el Nuevo Testamento Trilingüe de J. M. Bover y J. O’Callaghan-.

${ }^{80}$ MacCulloch 2009. Más allá de la provocación, el subtítulo apunta a la necesidad de comprender la génesis de la nueva religión en su matriz judía y en el contexto de la cultura grecorromana, a las que se dedican sendos capítulos.

${ }^{81}$ MacCulloch 2009, 91 (trad. española, MacCulloch 2011, 120).

82 En otros casos, ni siquiera se menciona que Jesús fue crucificado con otros hombres, obviándose el carácter colectivo de la ejecución del Gólgota. La omisión de material crucial para la comprensión de la figura lleva a repetir las típicas mistificaciones teológicas: «The Jesus of history remains elusive, tantalising, intriguing» (Young 2006, 24).
} 
solo lo que sabemos sobre la identidad de aquellos a los que la crucifixión fue aplicada por Roma en Palestina, sino también el contexto histórico inmediato ${ }^{83}$.

Se hace perceptible aquí que el problema de las obras al uso no se limita a traducciones erróneas ${ }^{84}$. Otra deficiencia estriba en dejar sin explicación adecuada material decisivo para la comprensión histórica de lo narrado. Incluso si se traduce con acierto $\lambda \eta\rceil \sigma \tau \alpha i ́$ por «bandidos»o «bandoleros», dejar el término sin comentar no puede sino inducir a confusión, pues todo indica que no constituye una designación fiable de la identidad de los crucificados, sino que -al igual que a menudo en Josefo- es un término denigratorio. Pues bien, la misma desidia y falta de sentido crítico que habría que achacar al historiador que no explicase la distorsión operada sobre el término

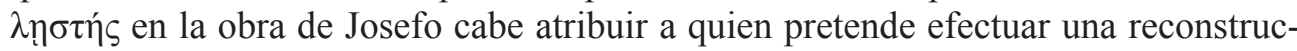
ción histórica de la vida y la muerte de Jesús silenciando un fenómeno análogo en los evangelios.

En tal tesitura, la visión que se transmite de la escena del Gólgota es totalmente distorsionada: esta deja de poseer sentido como una (comprensible) crucifixión colectiva de oponentes al Imperio para convertirse en un suceso ininteligible, en el que un sujeto, sin que se sepa por qué, es ejecutado en medio de dos delincuentes -aunque Roma, que sepamos, jamás crucificó en Judea a delincuentes comunes-. Que esta desorientadora presentación de un evento clave para la historia del cristianismo se reitere en tantas obras contemporáneas supuestamente rigurosas debería dar mucho que pensar.

\section{2. ¿FUE JESÚS ARRESTADO POR INICIATIVA DE LAS AUTORIDADES JUDÍAS?}

Según los evangelios canónicos, la iniciativa del arresto de Jesús -así como la responsabilidad por su crucifixión- se debe no al prefecto romano, sino a las autoridades judías. La noción aparece ya en Pablo (1 Tes 2, 15, de autoría disputada), pero son los relatos evangélicos los que la dotan de sustancia. Mientras que según Mc 3,6 son «los fariseos» y los «herodianos» los que se confabulan «para acabar con él», según Mc 11, 18 y 14, 1 es un colectivo diferente de implacables adversarios, a saber, «los sumos sacerdotes y los escribas», los que «buscaban la manera de acabar con él».

Habida cuenta del carácter extremadamente tendencioso de las fuentes evangélicas, cualquier historiador lúcido sabe que no es legítimo considerar fiable de inmediato un dato por el mero hecho de que conste en tales fuentes. A fortiori, dado que

\footnotetext{
${ }^{83}$ Cfr. supra, sección 3.2 .

${ }^{84}$ Dado que el autor de estas líneas se ocupó de la revisión de la primera edición española -infestada de errores de traducción- de A History of Christianity, sugirió al propio autor algunas correcciones con respecto al texto original. MacCulloch aceptó varias de ellas, y por ello la segunda edición española (aparecida en 2012) tiene en este caso «eran probablemente rebeldes políticos». El error, sin embargo, subsiste en la edición inglesa $\mathrm{y}$ en las traducciones efectuadas a otros idiomas.
} 
la insistencia en la participación judía en el arresto de Jesús constituye una estrategia apologética de la tradición evangélica, destinada a exculpar a Roma y, asimismo a distanciar de cualquier veleidad antirromana al guía de la secta nazarena y, por tanto, de paso, a alejar toda sospecha de la existencia de infidelidad al Imperio en las comunidades cristianas.

Pero hay otra razón aún más seria para poner en duda los relatos evangélicos del episodio del arresto, y es que hay poderosos argumentos a favor de una versión alternativa, tal y como ha sido señalado en diversas ocasiones. El cuestionamiento de la versión tradicional fue llevado a cabo hace ya más de un siglo, cuando Maurice Goguel, exegeta protestante y figura señera de la investigación sobre los orígenes del cristianismo en la primera mitad del s. XX, señaló en los relatos de la pasión toda una serie de indicios que traicionan la existencia de un relato original distinto, en el que los responsables del arresto de Jesús habrían sido las autoridades romanas ${ }^{85}$. Desde entonces, diversos autores han asumido y ampliado el argumentario ${ }^{86}$.

El carácter incongruente de los relatos del arresto y la tendencia redaccional a culpabilizar a los judíos son solo el elemental punto de partida. Para no repetir aquí el minucioso trabajo de otros autores, baste mencionar solo algunas de los argumentos ofrecidos ${ }^{87}$ : la mención, en el evangelio de Juan, de una cohorte $(\sigma \pi \varepsilon i \tilde{\rho} \alpha)$ y un tribuno

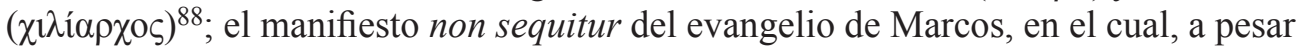
de la intención del autor de atribuir el arresto a las autoridades judías, el prefecto romano parece estar enterado ya de los cargos contra Jesús la primera vez que es introducido en la narración ${ }^{89}$; la llamativa frase de Jn 18, 36- «Si de este mundo fuera mi reino, mis ministros lucharían para que yo no fuera entregado a los judíos (îv $\alpha \mu \grave{\eta}$

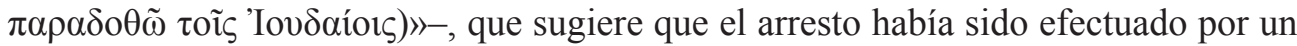
grupo no-judío, ${ }^{90}$ etc. De hecho, el dato más seguro de la historia de la pasión es el de que Jesús fue crucificado por los romanos, por lo que un escenario en el que hubiera sido arrestado por ellos tendría perfecto sentido. Si a esto se añade que -como todas las crucifixiones de las que tenemos noticia en Judea bajo dominación romana- la del Gólgota se trató de una crucifixión colectiva (de insurgentes), la probabilidad de que haya sido el prefecto el iniciador de todo el proceso aún se incrementa.

Conviene percatarse, no obstante, de que esto no significa necesariamente negar tout court alguna intervención de las autoridades judías en el procedimiento contra

85 Cfr. Goguel 1910. Lietzmann 1958, 260-261 ponderó también esta posibilidad (el texto «Der Prozeß Jesu» fue publicado originalmente en 1931, en los Sitzungsberichte der Preußischen Akademie der Wissenschaften, phil.-hist. Klasse 1931, XIV, 313-322).

${ }^{86}$ Cfr. Cohn 1972; E. Stegemann 1998, 920: «Ein vorgängiger jüdische Prozeß (vor dem Synedrion) ist ausgeschlossen, eine auch nur 'offiziöse' jüd. Beteiligung unwahrscheinlich»; E. Stegemann 2002; W. Stegemann 1998.

${ }^{87}$ Para un análisis pormenorizado de esta cuestión, cf. Bermejo 2015b.

88 Jn 18, 3-12. «It is likely that the editor exaggerated the strength of the detachment and the rank of the officer [...], but not that he freely invented the report of Jesus' arrest by the Romans» (Winter 1974, 61 n. 4).

${ }^{89}$ Cfr. Mc 15, 1. Así lo señaló Goguel 1910, 174, quien argumentó también que la laguna parece haber sido percibida por Lucas, que añade los cargos en 23, 2.

90 Cfr. Brandon 1967, 319 n. 6. 
Jesús (y su grupo), pues de ese modo sería más fácil explicar la canalización de la culpa en esas autoridades que si esta hubiera sido una pura invención ex nihilo. Ahora bien, la aceptación de esta posibilidad no implicaría -nótese bien- volver a la interpretación evangélica de los hechos, y por tanto no exigiría asumir una iniciativa de las autoridades judías. Como ya conjeturó el propio Goguel, esa intervención podría haberse limitado a una mera consulta preventiva de Pilato con el fin de asegurarse de que por parte de las autoridades locales no hubiera oposición a su acción contra Jesús (y su grupo $)^{91}$.

Por supuesto, es en principio legítimo ir más allá y contemplar la posibilidad de una iniciativa de las autoridades judías, pues estas tenían la responsabilidad de conservar el orden público en Jerusalén, so pena de una intervención -inevitablemente sangrienta- de las tropas romanas. En este sentido, un escenario como el dibujado en Jn 11, 47-50 (independientemente de la historicidad literal de lo formulado en esta perícopa) no puede desecharse definitivamente. Ahora bien, en este caso las razones que explican la intervención habrían sido exclusivamente políticas. Además, esa actuación debería ser entendida a la luz de una situación de dominio imperial; es decir, no habría sido una iniciativa propiamente dicha, o solo en un nivel muy superficial, pues las autoridades judías habrían actuado probablemente bajo compulsión, como reacción a una presión previa-implícita o explícita- del poder de ocupación ${ }^{92}$. En cualquier caso, esto no es más que una hipótesis.

En estas circunstancias, todo estudioso lúcido debería informar a sus lectores no solo de las dificultades de una reconstrucción histórica, sino también de la existencia de alternativas razonables a los relatos evangélicos. Una vez más, sin embargo, estas expectativas se ven defraudadas. Todavía hoy en día, en efecto, innumerables historiadores -incluso muchos de los que presumen de adoptar un enfoque independiente $^{93}$ - siguen asumiendo sin discusión la versión evangélica de los hechos ${ }^{94}$. En

\footnotetext{
${ }^{91}$ Goguel 1910, 321. Contra la habitual asunción -reflejo de los relatos evangélicos- de que Jesús fue el único miembro de su grupo en el que las autoridades estaban interesadas, cfr. Bermejo 2013a, passim.

${ }^{92}$ Así lo argumentó Winter 1974, 57. En este sentido, se ha afirmado con razón que una colaboración de las autoridades judías es concebible solo si estas son consideradas «Teil des Systems der römischen Ordnungsund Polizeipolitik» (Stegemann 2002, 34, cursivas originales). Aunque podrían aducirse casos de autoridades judías que decidieron entregar y denunciar a los romanos a correligionarios que podían causar serios problemas (los sicarii en Egipto: B. J. VII 409-419), también los hay del rechazo a hacerlo, como ocurrió en Judea en tiempos de Floro (B. J. II 297-304).

${ }^{93}$ Omito aquí, por tanto, obras como la de Ribas Alba 2004, que -a pesar de estar publicada en una colección de «Ciencia jurídica»- postula el carácter sobrenatural de los relatos evangélicos y está caracterizada por una extrema credulidad: el autor asume la fiabilidad de la práctica totalidad del texto, con resultados históricamente inverosímiles.

94 «I do not doubt that Jesus was arrested on the orders of the high priest and interrogated» (Sanders 1985, 299); «Es evidente que la iniciativa de la acusación partió de las autoridades religiosas judías» (Teja 1990, 23); «Es, ciertamente, indudable que su condena a muerte en la cruz fue decidida y ejecutada por la autoridad romana, aunque de manera sumarísima y con la complicidad de algunos sacerdotes y dirigentes judíos» (Fernández Ubiña 2000, 167); «The narrative of Jesus' arrest is also historically accurate» (Casey 2010, 439); entre muchos otros. Esta posición alcanza su clímax cuando se niega explícitamente la posibilidad de un escenario alternativo al de los relatos evangélicos: «an exclusively Roman (!) course of action against Jesus is not at all intelligible [...] no reason for direct Roman action against Jesus is detectable» (Broer 2007, 163, 167, signo de admiración original).
} 
muchos de estos casos es difícil decidir si resulta más inquietante la asunción de un incongruente relato hagiográfico o la seguridad - «es evidente...», «es indudable...»con la que tal asunción tiene lugar. Otro caso reciente es la contribución de Miguel Pérez Fernández a una Historia del cristianismo elaborada por autores españoles. En ella, este autor afirma:

Sin duda ninguna en el proceso influyó la denuncia de la aristocracia jerosolimitana ${ }^{95}$

Es este otro ejemplo de aseveración típicamente temeraria e irresponsable, dada la gran cantidad de dudas fundadas que existen ${ }^{96}$. Añadamos otra: el escrito no bíblico que suele aducirse a favor de una iniciativa judía en el arresto -el Testimonium Flavianum contiene la frase «Pilato lo condenó a morir en la cruz por instigación de las autoridades de nuestro pueblo» ${ }^{97}$ - no solo fue a todas luces retocado por piadosos escribas, por lo que la autoría cristiana de la frase citada no puede descartarse ${ }^{98}$, sino que su Vorlage fue, como el resto de las Antiquitates Judaicae de Josefo, escrita a finales del s. I, por lo que podría reflejar ideas cristianas ${ }^{99}$. Es responsabilidad elemental del historiador señalar la existencia de todas estas dudas a sus lectores, al igual que es su deber matizar sus afirmaciones y ser fiel al carácter de la reconstrucción histórica, que es hipotética por definición; máxime, cuando nos las vemos con fuentes sesgadas de hace dos milenios. En este caso, «sin duda ninguna» indica una certeza absoluta que tiene que ver mucho menos con la investigación crítica que con la credulidad, por no decir con la fe y el dogma.

Dar por evidente o indudable lo que no lo es en absoluto no es solo efectuar afirmaciones demostrablemente falsas, sino limitarse a reflejar la versión evangélica y situarse con ello en un horizonte precrítico. Lo que, una vez más, resulta grave es que la cuestión de la identidad de los responsables del arresto de Jesús no es en modo alguno secundaria para la comprensión de esta figura y más genéricamente para una intelección cabal del Nuevo Testamento.

\footnotetext{
95 Pérez Fernández 2003, 110. Tanto en este autor como en los autores citados en la nota anterior -así como en las de muchos otros autores contemporáneos-, las referencias a los argumentos contenidos en las obras citadas de Goguel y Lietzmann brillan por su ausencia.

${ }^{96}$ La afirmación señalada no es el único juicio temerario del autor: «Es un dato cierto que Jesús durante su vida pública no se proclamó a sí mismo mesías o rey» (Pérez Fernández 2003, 109). Sobre tal «certeza», cfr. supra, 3.3.

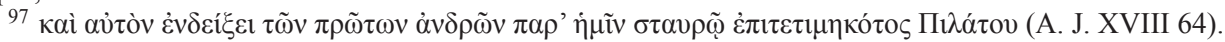

${ }^{98}$ Así lo han sostenido varios autores, dado que la frase casa tan bien con el relato evangélico; cfr. Dubarle 1973, 495-498; Olson 1999, 311. Aunque otros autores (como P. Winter o J. P. Meier) han objetado que un interpolador cristiano habría enfatizado más el papel judío, en un pasaje tan breve una mención como la del textus receptus puede haber sido juzgada suficiente. Innumerables estudiosos, sin embargo, se limitan a presuponer la genuinidad del texto.

99 "Given that Josephus was writing towards the first century, he could have been indirectly reflecting Christian claims that in turn reflected the Gospels or the traditions immediately behind them» (Eve 2005, 42).
} 


\section{3. ¿FUE JESÚS CONDENADO POR «BLASFEMIA»?}

Un conocido pasaje del evangelio de Marcos describe a Jesús siendo interrogado por el sumo sacerdote, y al consejo juzgando unánimemente a este por blasfemia: «De nuevo el sumo sacerdote le interrogaba, diciéndole: '¿Eres tú el mesías, el hijo del Bendito?'. Jesús dijo: 'Yo soy, y veréis al hijo del hombre sentado a la diestra del Poder y viniendo entre las nubes del cielo'. El sumo sacerdote, rasgando sus túnicas, dice: ¿¿Qué necesidad tenemos aún de testigos? Habéis oído la blasfemia. ¿Qué os parece?'. $\mathrm{Y}$ todos ellos le condenaron como reo de muerte» ${ }^{100}$. Esto significa que la causa de la crucifixión según la versión en la que insisten los evangelistas es religiosa, no política. Y esto implica, a su vez, que los iniciadores de la acción contra Jesús habrían sido judíos.

Una vez más, el problema con esta explicación no es solo ni principalmente que sea la ofrecida por fuentes sesgadas. La historicidad del pasaje presenta numerosos problemas, como ha sido señalado en la historia de la investigación ${ }^{101}$. El marco en que se sitúa - una sesión nocturna del Sanedrín- vulnera en diversos aspectos las disposiciones de la Misná102. La adición de «el hijo del Bendito» a «el Cristo» en la pregunta del sumo sacerdote parece atribuir divinidad al mesías, en contra de la práctica judía habitual, por lo que es posible -y aun probable-que refleje una concepción cristiana ${ }^{103}$. La idea de un Jesús que vendrá en gloria en las nubes casa muy bien con las expectativas de los primeros nazarenos - pero no es seguro que estas fueran las del propio Jesús-. La naturaleza religiosa del cargo hace sorprendente la entrega de Jesús a Pilato con una acusación política, cuando la sentencia parecería exigir una ejecución de acuerdo a la ley judía y cuando no hay equivalencia clara entre los dos cargos ${ }^{104}$. Por si fuera poco, la blasfemia no aparece por ninguna parte en los pasajes referidos a los cargos presentados contra Jesús ante el prefecto.

Estos y otros problemas han ocasionado muchos quebraderos de cabeza a los interesados en defender la credibilidad de los relatos evangélicos, dando lugar a todo tipo de conjeturas para intentar dotar a la escena de Marcos de verosimilitud ${ }^{105}$. Un ejemplo elocuente es una monografía de Darrell L. Bock en la que se afirma que la respuesta de Jesús en Mc 14, 62 combina una alusión a la autoridad de una figura real (Sal 110, 1) con la figura de «uno como un hijo de hombre» de Dan 7, 13 y que esta combinación ofrece la clave para comprender la «blasfemia» ${ }^{106}$. La idea es que, aunque Jesús no habría

\footnotetext{
100 Mc 14, 61-64; cfr. Mt 26, 65.

101 Cfr. p. ej. Sanders 1985, 296-306, esp. 297-298, quien enumera siete dificultades distintas.

102 Suele admitirse que los procedimientos recogidos en mSanh reflejan usos anteriores. Cfr. Reinbold 1994, 252.

103 Cfr. Lietzmann 1958, 255; Brandon 1967, 7.

104 Cfr. Lietzmann 1958, 275.

${ }^{105}$ Los intentos comienzan ya en los propios evangelios. Jn 18, 31 hace decir a las autoridades judías que ellas no están autorizadas a ejecutar a nadie. Esta supuesta incapacidad ha sido cuestionada por varios estudiosos modernos: cfr. Juster 1914, II, 127-142; Winter 1974, 75-90. La frase joánica tiene todos los visos de ser una racionalización para el hecho de que Jesús fue crucificado por los romanos, a pesar de que los evangelios pretenden que fue condenado por los judíos.

${ }^{106}$ Cfr. Bock 1998. El autor se refiere a un «growing consensus among many scholars that the key to the blasphemy resides in the functions Jesus claims through the combination of Ps 110:1 and Dan 7: 13» (Bock 1998,
} 
cometido blasfemia en el sentido restringido de usar el nombre divino de un modo inapropiado, su autoexaltación como juez escatológico habría sido considerada como una afrenta blasfema al honor de Dios, y también como un ataque a los dirigentes de Israel.

Es importante advertir, de entrada, la extrema fragilidad epistemológica de tal explicación. En efecto, esta obliga a aceptar toda una serie de hipótesis auxiliares, como por ejemplo: que la escena descrita por Marcos no pretende describir un juicio capital, sino solo una vista preliminar (de modo que no colisiona con las prescripciones misnaicas); que Jesús pronunció realmente las palabras que se le atribuyen en Mc 14, 62; que esas palabras implican que Jesús se identificó con el juez escatológico que vendría sobre las nubes del cielo ${ }^{107}$; que hubo testigos que registraron fielmente lo dicho y lo transmitieron a miembros de la comunidad nazarena ${ }^{108}$; que los dirigentes judíos habrían interpretado lo dicho como blasfemia, y no -por ejemplo-como el disparate de un visionario ${ }^{109}$; que esos dirigentes no tenían la potestad de aplicar la pena capital por delitos religiosos; que las máximas autoridades judías habrían traído a colación Ex 22, 27, y que no habrían tenido escrúpulos en entregar a los romanos, para su ejecución, a uno de sus propios correligionarios; etc. Cada una de estas hipótesis es dudosa en sí misma, pero la acumulación de todas ellas aumenta exponencialmente la improbabilidad de la «explicación» que las presupone.

Además, es menester señalar que se han ofrecido explicaciones muy plausibles para la creación de diversos aspectos clave de los relatos de la pasión a partir de datos provenientes del período inmediatamente anterior a la primera Guerra Judía. En particular, la sesión (o sesiones) del sanedrín y la responsabilidad atribuida al sumo sacerdocio en la condena de Jesús se hacen más comprensibles si -como ha argumentado Jonathan Bourgel en una importante contribución- reflejan el descrédito de esta institución debido a la arbitrariedad de algunas actuaciones y procedimientos jurídicos que, según testimonia Flavio Josefo, tuvieron lugar a principios de los años 60 del s. I, y que fueron orquestados por el sumo sacerdote Anás ${ }^{110}$. Esto hace probable que tales juicios irregulares hayan servido de modelo literario para la creación de la comparecencia de Jesús ante el sanedrín, lo que aumenta la probabilidad de que las escenas evangélicas de un juicio judío no sean históricamente fiables.

Ahora bien, el carácter extremadamente dudoso de una explicación basada en la presunta blasfemia no estriba solo en los problemas internos que presenta el pa-

26). Sin embargo, la validez de tal «consenso» es falaz, pues este se refiere en todo caso a una opinión existente en un ámbito confesional interesado en salvar a toda costa la credibilidad de los relatos evangélicos, y en especial su idea nuclear: que Jesús fue una víctima inocente y que los responsables de su muerte fueron los (espiritualmente inferiores) judíos. Este «consenso» tiene un valor similar al del existente en la Unión Soviética respecto a la validez de las doctrinas de Lenin, o al del que había en su tiempo en China en relación a las doctrinas de Mao.

${ }^{107}$ Obsérvese que solo Mateo y Lucas indican que la visión de la figura escatológica mencionada será

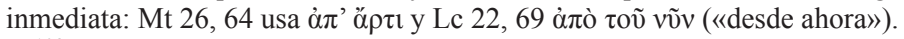

${ }^{108}$ Bock -que no parece conocer la obra citada de Goguel- simplemente presupone la fiabilidad del texto evangélico con respecto a la iniciativa de las autoridades judías. Entre las potenciales fuentes de información que habrían podido transmitir cita a personajes evangélicos como José de Arimatea o Nicodemo...

${ }^{109}$ Como conjeturó sensatamente Lietzmann 1958, 255-256.

110 Bourgel 2012, 506-513. 
saje de Mc 14, 61-64, en el carácter enrevesado y metodológicamente frágil de las interpretaciones que intentan postular su historicidad o en el carácter posiblemente anacrónico de los relatos en que se sustenta. El principal problema de tal «explicación», en efecto, no es otro que el de que -como hemos visto- hay una hipótesis que elucida del modo más natural y convincente el hecho de que Jesús fue crucificado por los romanos: la de que el visionario galileo estuvo implicado en la resistencia antirromana. Esta hipótesis tiene varias características que la hacen preferible desde un punto de vista científico, a saber, su simplicidad, su respaldo textual, su plausibilidad contextual y su amplísimo (e inigualado) poder explicativo. La existencia de razones suficientes en el ámbito político romano para ejecutar a Jesús -y, en lo posible, a algunos de sus seguidores- hace no solo sospechosas sino del todo superfluas las especulaciones que intentan hacer respetables las racionalizaciones evangélicas relativas a motivos religiosos.

A esta luz, no es necesario emprender una refutación detallada de los siempre renovados intentos por dotar de fiabilidad al texto evangélico. De hecho, se revela aquí con toda nitidez su carácter pseudohistórico: mientras que una explicación rigurosa solo puede fundarse sobre las hipótesis -ceteris paribus- más probables, las estrategias confesionales o paraconfesionales consisten en silenciar o minimizar las hipótesis que presentan todos los visos de probabilidad, para, a renglón seguido y con toda desenvoltura, inferir historicidad de lo que es, en el mejor de los casos, vagamente verosímil (o no del todo inverosímil) ${ }^{111}$. Esto significa que las versiones al uso incurren en la falacia possibiliter ergo probabiliter, a pesar de que hace ya casi dos siglos Ferdinand Christian Baur advertía de que en la investigación histórica nada mínimamente fiable puede obtenerse mientras uno se atenga a lo meramente posible, pues es en lo probable donde lo real tiene trazas de descubrirse ${ }^{112}$.

Las consideraciones anteriores permiten juzgar la credibilidad de las reconstrucciones cuyos autores intentan convencerse, y persuadir a sus lectores, de que el cargo evangélico de blasfemia posee capacidad explicativa y respetabilidad intelectual. En la estela de la omnipresente interpretatio christiana, este es en efecto el estribillo, hasta hoy, de infinidad de trabajos académicos, algunos de los cuales poseen el estatus de obras de referencia ${ }^{113}$. El volumen editado por Bock y Webb es otro caso reciente ${ }^{114}$. En nuestro país, baste con señalar la contribución de Miguel Pérez

\footnotetext{
111 Este es precisamente el procedimiento seguido por Darrell Bock y por tantos otros. El uso de lo meramente verosímil y de la doble negación («not implausible») se da con profusión en Brown 1994, 586, $721,915,940,1027,1192$, etc.

112 «Es ist daher überhaupt mit der bloßen Berufung auf die Möglichkeit auf dem Standpunkt der geschichtlichen Betrachtung nichts ausgerichtet, weil die Geschichte es nicht mit dem Möglichen, sondern dem Wirklichen zu thun hat. Was aber wirklich ist oder nicht, kann nicht nach der Möglichkeit, sondern nur nach der Wahrscheinlichkeit beurtheilt werden» (Baur 1847, 21).

113 Cfr. p. ej. Betz 1982, 633-639; Brown 1994, I, 516-547; Bryan 2005, 59; Brent 2009, 31; entre muchos otros.

114 «For Jesus had made claims that the Jewish authorities did consider a threat - Jesus' claims were an offense to their religious and theological sensibilities» (Webb en Bock y Webb 2009, 758). La blasfemia se presupone en muchos de los capítulos de este mismo volumen, y es el tema abordado en el de Darrell Bock.
} 
Fernández a la ya mencionada Historia del cristianismo $^{115}$, aunque los ejemplos se hallan por doquier.

Dada la generalizada falta de rigor, es natural encontrarla también en las obras destinadas al gran público. Así ocurre en las páginas dedicadas a Jesús en el volumen «Religiones y culturas» de la Enciclopedia del Estudiante, una colección vendida con el periódico El País y que presuntamente cuenta con el asesoramiento de especialistas ${ }^{116}$. Tras una presentación en que Jesús es, de entrada, aislado de modo simplista del judaísmo contemporáneo (su mensaje «rompía tanto con el punto de vista estricto en el cumplimiento de la Torá que defendían los fariseos, como con el papel de máxima importancia que los saduceos otorgaban al templo. Tampoco se ajustaba a los estrictos modos de vida de los esenios») y varias afirmaciones peregrinas que reflejan la teología de los evangelistas - del tipo «fue señalado por Juan el Bautista como su sucesor»-, se asevera que en su viaje a Jerusalén «su presencia y lo que predicaba le enfrentaron a las autoridades judías y a los que les obedecían» ${ }^{117}$. Por si no quedara claro lo que se pretende decir, se explicita a continuación:

Jesús fue hecho prisionero por los guardias del sumo sacerdote y llevado ante el consejo religioso judío, el sanedrín. Se le declaró culpable de blasfemia y fue entregado a las autoridades romanas para que le fuera aplicada la pena de muerte. Entonces, el gobernador romano de Judea, Poncio Pilato, plegándose a lo que le solicitaban las autoridades judías, condenó a muerte a Jesús, que fue crucificado $^{118}$

Arresto judío de Jesús, juicio por el sanedrín, condena por blasfemia, papel solo secundario e instrumental del prefecto romano en la crucifixión... se constata así una perfecta sinergia entre el ámbito universitario y el escolar. Mientras que en la academia la mayoría de estudiosos reproduce la ficción, a fortiori se vende a los estudiantes una paráfrasis de los evangelios en calidad de historia: todos los elementos de la fábula apologética, y sin el menor matiz de cuestionamiento, son perpetuados para uso de las jóvenes generaciones. Siglos de investigación filológica e histórica quedan reducidos a escombros. Al fin y al cabo, ¿para qué esforzarse en estar a la altura de la crítica científica, cuando la familiaridad del mito hace tan sumamente fácil su reiteración?

\footnotetext{
115 Aunque el autor se refiere genéricamente a la existencia de «indicios que podían mostrar a Jesús como un revolucionario peligroso» (Pérez Fernández 2003, 110), obvia enteramente su tratamiento. Este autor presupone sin crítica alguna la iniciativa de las autoridades judías y se atiene a la explicación tradicional; a lo largo de varias páginas (ibid., 110-112), el término «blasfemia» y sus cognados se repiten como una letanía.

116 Como director del equipo encargado del volumen «Religiones y culturas» figura Francisco Díez de Velasco.

117 VV.AA. 2005, 226.

118 Ibid., 228.
} 


\section{CONCLUSIONES Y REFLEXIONES ULTERIORES}

Los evangelios son obras de propaganda religiosa cuyos destinatarios compartían ya las ideas básicas de sus autores; para ellos, la determinación de la fiabilidad histórica de esos relatos no era una prioridad ni un problema, pues tal fiabilidad o se presuponía o no interesaba: a los ojos de la fe, los relatos expresan la verdad que otorga sentido metaempírico y consuelo a la vida de los cristianos, tanto más cuanto que la dramática historia narrada en estos escritos -la de un ser ontológica y moralmente excepcional, víctima inocente de una conspiración de odium theologicum por parte de una colectividad desalmada- resulta vívida y profundamente cautivadora, a tal punto que para muchos oyentes y lectores a lo largo de los siglos ha poseído indudable verosimilitud.

Un juicio muy diferente es el que emite el historiador de las religiones al adoptar una perspectiva etic sobre esos textos sin dejarse seducir por su aura sacra. Aparte de sus elementos sobrenaturales y legendarios, existen sólidas razones para inferir que los relatos de la pasión, incluso allí donde parecen prima facie informes de acontecimientos, contienen una versión distorsionada e incongruente que -más allá del hecho de que una crucifixión colectiva tuvo lugar bajo Pilato, de que la condena estuvo relacionada con las pretensiones regias de Jesús y de algunos otros detalles- carece de fiabilidad, siendo en gran parte una ficción piadosa. El cuestionamiento de los relatos evangélicos no conduce, empero, a un total escepticismo, pues existen rastros de una historia subyacente que permiten al estudioso una reconstrucción alternativa mucho más plausible que la narrada en aquellos. Si tal labor priva de fundamento a creencias compartidas por muchos de sus contemporáneos es algo que al historiador de las religiones le dejará impertérrito: al fin y al cabo, la disciplina de la que se ocupa posee desde sus orígenes una irrenunciable vocación de lucidez, ajena a los dictados de la piedad y del consuelo ofrecido por la fantasía.

Resulta por ello tan elocuente como decepcionante constatar que tantas obras contemporáneas, al abordar la figura del judío Jesús, se hallan muy por debajo de los estándares de rigor, neutralidad, sentido crítico y plausibilidad que se aplican en otros campos, y que cabría esperar a estas alturas del curso de la investigación. La sombra de las Sagradas Escrituras es alargada, y la sesgada versión evangélica, aceptada durante siglos en calidad de historia, continúa haciendo estragos en el mundo académico, pues su núcleo sigue siendo reproducido con pasmosa credulidad como respetable historia (de las religiones), sea en forma de paráfrasis o en un híbrido criptoteológico de historia y ficción ${ }^{119}$. Esto significa que la versión emic/insider se impone y se hace

\footnotetext{
${ }^{119}$ Varios factores contribuyen a explicar este estado de cosas: el escaso conocimiento que muchos historiadores del cristianismo tienen del judaísmo; la insuficiente familiaridad con la literatura crítica y la dependencia con respecto a una abundantísima producción confesional (indefectiblemente presentada como historia rigurosa); la atrofia del sentido histórico producida en virtud de los factores anteriores; el temor a herir sensibilidades, dado que la crítica amenaza creencias arraigadas; y la disposición a las componendas en un ámbito en el que gran parte de especialistas provienen de ámbitos confesionales y poseen instrumentos -editoriales, universidades, organización de congresos y publicaciones...- que son útiles para el resto de
} 
pasar como etic/outsider, en una eficaz mímesis que habría atribulado sobremanera a Platón. Dados los muchos intereses en juego, debería ser claro que esta descorazonadora situación está llamada a perpetuarse sine die.

Aun siendo las deficiencias epistémicas señaladas lo bastante graves y preocupantes, no es todo lo que aquí se halla en juego. Un mito fundacional de Occidente ha sido construido en los evangelios mediante una distorsión de la historia efectuada a costa de la victimización y el ennegrecimiento moral de una colectividad (sea el pueblo judío, sean las autoridades religiosas de Judea) que - una vez que la secta nazarena, convertida en religión autónoma, adquirió poder en el Imperio- fue más allá del plano literario para convertirse en realidad. Lo que en su origen había sido una polémica sectaria intrajudía adquirió nuevas dimensiones, produciendo una inflexión decisiva en la historia del antijudaísmo que ha alentado a lo largo de los siglos discursos $\mathrm{y}$ actos a menudo criminales, con las funestas consecuencias de todos conocidas ${ }^{120}$. Una reconstrucción de la figura de Jesús que renuncia a ejercer una crítica consistente de la ficción evangélica y que en aspectos clave sigue dependiendo de ella de manera servil no solo está condenada a distorsionar la historia, sino también, nolens volens, a hacerse cómplice de otros inquietantes fenómenos. En estas circunstancias, denunciar las deficiencias de la historiografía contemporánea no es solo un elemental deber intelectual sino también un inexcusable -aunque quizás inútil-imperativo ético.

\section{BIBLIOGRAFÍA}

D. C. Allison, Constructing Jesus. Memory, Imagination, and History, Grand Rapids, 2010.

E. Bammel, «The Trial before Pilate», en E. Bammel - C. F. D. Moule (eds.), Jesus and the Politics of His Day, Cambridge, 1984, 415-451.

F. C. Baur, Kritische Untersuchungen über die kanonischen Evangelien, ihr Verhältnis zu einander, ihren Charakter und Ursprung, Tübingen, 1847.

F. W. Beare, The Earliest Records of Jesus, New York - Nashville, 1962.

F. Bermejo, «La relevancia de las soteriologías gnósticas y maniquea para una crítica de la pseudociencia de la religión», en J. J. Fernández Sangrador - S. Guijarro (eds.), Plenitudo Temporis. Miscelánea Homenaje al Prof. Ramón Trevijano Etcheverría, Salamanca, 2002, 333-346.

F. Bermejo, «La figura histórica de Jesús y los patrones de recurrencia. Por qué los límites de los criterios de autenticidad no abocan al escepticismo», Estudios Bíblicos 70 (2012) 371-401.

\footnotetext{
sus colegas. En estas circunstancias, no pocos estudiosos prefieren contemporizar con el objeto de no ver disminuidas sus redes de influencia y de que su afán de medro personal y curricular no sufra perjuicios.

${ }^{120}$ La supuestamente cínica manipulación del presunto procedimiento contra Jesús por parte de las autoridades judías es postulada a menudo de forma explícita o implícita: esas autoridades habrían preferido «expediency to honor and convenience to justice» (Bryan 2005, 62). En este sentido se ha afirmado con razón: «The passion narratives challenge both the honesty of Christian history and the integrity of Christian conscience» (Crossan 1995, 36).
} 
F. Bermejo, «(Why) Was Jesus the Galilean Crucified Alone? Solving a False Conundrum», Journal for the Study of the New Testament 36 (2013a) 127-154.

F. Bermejo, «Has the Hypothesis of a Seditionist Jesus Been Dealt a Fatal Blow? A Systematic Answer to the Doubters», Bandue 7 (2013b) 19-57.

F. Bermejo, «Why is John the Baptist used as a Foil for Jesus? Leaps of Faith and Oblique Anti-Judaism in Contemporary Scholarship», Journal for the Study of the Historical Jesus 11 (2013c) 170-196.

F. Bermejo, «Was the Hypothetical Vorlage of the Testimonium Flavianum a 'Neutral' Text? Challenging the Common Wisdom on Antiquitates Judaicae XVIII 63-64», Journal for the Study of Judaism 45 (2014a) 326-365.

F. Bermejo, «Jesus and the Anti-Roman Resistance. A Reassessment of the Arguments», Journal for the Study of the Historical Jesus 12 (2014b) 1-105.

F. Bermejo, «Jesus as a Seditionist: the Intertwining of Politics and Religion in his Teaching and Deeds», en Z. Garber (ed.), Teaching the Historical Jesus. Issues and Exegesis, London - New York, 2015a, 232-243.

F. Bermejo, «'Y vendrán los romanos...' (Jn 11, 48). Sobre la identidad de los responsables del arresto de Jesús el galileo», en I. Muñoz Gallarte y D. Romero (eds.), Nova et Vetera. Philological Studies in Honor of Professor Antonio Piñero, Córdoba, 2015b, en prensa.

O. Betz, «Probleme des Prozesses Jesu», ANRW II.25.1, Berlin - New York, 1982, 565-647.

J. Blenkinsopp, «The Oracle of Judah and the Messianic Entry», Journal of Biblical Literature 80 (1961) 55-64.

J. Blinzler, «Die Niedermetzelung von Galiläern durch Pilatus», Novum Testamentum 2 (1957) 24-49.

D. L. Bock, Blasphemy and Exaltation in Judaism and the Final Examination of Jesus. A Philological-Historical Study of the Key Jewish Themes Impacting Mark 14:61-64, Tübingen, 1998.

D. L. Bock - R. L. Webb (eds.), Key Events in the Life of the Historical Jesus. A Collaborative Exploration of Context and Coherence, Tübingen, 2009.

J. Bourgel, «Les récits synoptiques de la Passion préservent-ils une couche narrative composée à la veille de la Grande Révolte Juive? », New Testament Studies 58 (2012) 503-521.

S. G. F. Brandon, Jesus and the Zealots. A Study of the Political Factor in Primitive Christianity, Manchester, 1967.

S. G. F. Brandon The Trial of Jesus of Nazareth, London, 1968.

A. Brent, A Political History of Early Christianity, London - New York, 2009.

I. Broer, «The Death of Jesus from a Historical Perspective», en T. Holmén (ed.), Jesus from Judaism to Christianity: Continuum Approaches to the Historical Jesus, London, 2007, 145-168.

R. E. Brown, The Death of the Messiah, 2 vols, New York, 1994.

C. Bryan, Render to Caesar. Jesus, the Early Church, and the Roman Superpower, Oxford, 2005.

J. Carmichael, The Death of Jesus, New York, 1982. 
M. Casey, Jesus of Nazareth. An Independent Historian's Account of his Life and Teaching, London - New York, 2010.

H. Cohn, The Trial and Death of Jesus (London 1972; original hebreo).

J. D. Crossan, Who Killed Jesus? Exposing the Roots of Anti-Semitism in the Gospel Story of the Death of Jesus, New York, 1995.

J. G. Crossley, Jesus in an Age of Terror. Scholarly Projects for a New American Century, London - Oakville 2008.;

W. D. Davies, The Gospel and the Land. Early Christianity and Jewish Territorial Doctrine, Sheffield, $1994^{2}$ ).

F. Díez de Velasco, «El estudio de la religión: autonomía, neutralidad, pluralidad», en F. Díez de Velasco - F. García Bazán (eds.), El estudio de la religión, Madrid, 2002, 361-401.

C. H. Dodd, Historical Tradition in the Fourth Gospel, Cambridge, 1963.

A.-M. Dubarle, «Le témoignage de Josèphe sur Jésus d'après la tradition indirecte», Revue Biblique 80 (1973) 481-513.

B. D. Ehrman, Forgery and Counterforgery. The Use of Literary Deceit in Early Christian Polemics, Oxford, 2013.

R. Eisler, IH $\Sigma O Y \Sigma B A \Sigma I \Lambda E Y \Sigma O Y B A \Sigma I \Lambda E Y \Sigma A \Sigma$. Diemessianische Unabhängigkeitsbewegung vom Auftreten Johannes des Täufers bis zum Untergang Jakobs des Gerechten, 2 vols., Heidelberg, 1929-1930.

E. Eve, «Meier, Miracle and Multiple Attestation», Journal for the Study of the Historical Jesus 3 (2005) 23-45.

W. R. Farmer, Maccabees, Zealots, and Josephus: An Inquiry Into Jewish Nationalism in the Greco-Roman Period, New York, 1956.

J. Fernández Ubiña, Cristianos y militares: la Iglesia antigua ante el ejército y la guerra, Granada, 2000.

M. Goguel, «Juifs et Romains dans l'histoire de la Passion», Revue de l'histoire des religions 62 (1910) 165-182, 295-322.

R. González Salinero, Las persecuciones contra los cristianos en el Imperio romano, Madrid, $2015^{2}$.

J. B. Green, «Crucifixion», en M. Bockmuehl (ed.), The Cambridge Companion to Jesus, Cambridge, 2001, 87-101.

H. W. Hoehner, Herod Antipas, London, 1972.

J. Juster, Les Juifs dans l'Empire Romain: leur condition juridique, économique et sociale, 2 vols., New York, 1914.

K. Kautsky, Der Ursprung des Christentums. Eine historische Untersuchung, Stuttgart, 1908.

H.-W. Kuhn, «Die Kreuzesstrafe während der frühen Kaiserzeit. Ihre Wirklichkeit und Wertung in der Umwelt des Christentums», ANRW II 25.1, Berlin - New York, 1982, 648-793.

S. Légasse, Le procès de Jésus. L’histoire, Paris, 1994.

H. Lietzmann, «Der Prozeß Jesu», en Id., Kleine Schriften II: Studien zum Neuen Testament (ed. K. Aland), Berlin, 1958, 251-276. 
A. Loisy, L'Évangile selon Luc, Paris, 1924.

H. Maccoby, Revolution in Judaea. Jesus \& The Jewish Resistance, London, 1973.

D. MacCulloch, A History of Christianity. The First Three Thousand Years, Penguin, 2009 (trad. cast., Historia de la cristiandad, Barcelona, 2011).

J. Marcus, «Crucifixion as Parodic Exaltation», Journal of Biblical Literature 125 (2006) 73-87.

D. B. Martin, «Jesus in Jerusalem: Armed and Not Dangerous», Journal for the Study of the New Testament 37 (2014) 3-24.

J. Martín Velasco, Introducción a la fenomenología de la religión, Madrid, 19966 (orig. 1978).

J. Montserrat Torrents, El galileo armado. Historia laica de Jesús, Madrid, 2007.

C. Moss, The Myth of Persecution. How Early Christians Invented a Story of Martyrdom, New York, 2013.

K. A. Olson, «Eusebius and the Testimonium Flavianum», Catholic Biblical Quarterly 61 (1999) 305-322.

M. Pérez Fernández, «Jesús de Galilea», en M. Sotomayor - J. Fernández Ubiña (eds.), Historia del cristianismo, I: El mundo antiguo, Madrid, 2003, 69-121.

A. Piñero, «Jesús y la política de su tiempo», en E. Ruiz Barrachina, El discípulo, Barcelona, 2010, 217-311.

G. Puente Ojea, Ideología e Historia. La formación del cristianismo como fenómeno ideológico, Madrid, 1974.

W. Reinbold, Der älteste Bericht über den Tod Jesu: Literarische Analyse und historische Kritik der Passionsdarstellungen der Evangelien, Berlin, 1994.

J. M. Ribas Alba, El proceso a Jesús de Nazaret. Un estudio histórico-jurídico, Granada, 2004.

E. P. Sanders, Jesus and Judaism, London, 1985.

A. N. Sherwin-White, Roman Society and Roman Law in the New Testament, Oxford, 1963.

E. Stegemann, «Jesus von Nazareth», Der Neue Pauly 5, Stuttgart, 1998, 910-922.

E. Stegemann, «Wie im Angesicht des Judentums historisch vom Tod Jesu sprechen?», en G. Häfner - H. Schmid (eds.), Wie heute vom Tod Jesu sprechen?, Freiburg i. Br., 2002, 23-52.

W. Stegemann, «Gab es eine jüdische Beteiligung an der Kreuzigung Jesu?», Kirche und Israel 13 (1998) 3-26.

W. Stegemann, Jesus und seine Zeit, Stuttgart, 2010.

R. Teja, El cristianismo primitivo en la sociedad romana, Madrid, 1990.

G. Theissen, Lokalkolorit und Zeitgeschichte in den Evangelien. Ein Beitrag zur Geschichte der synoptischen Tradition, Göttingen, 1989.

VV.AA., La Enciclopedia del Estudiante. Vol. 19: Religiones y Culturas, Madrid, 2005.

P. Winter, On the Trial of Jesus, Berlin, $1974^{2}$.

F. M. Young, «Prelude: Jesus Christ, Foundation of Christianity», en M. M. Mitchell - F. M. Young (eds.), The Cambridge History of Christianity, vol. 1: Origins to Constantine, Cambridge, 2006, 1-34. 